\title{
Mersin, Tarsus ve Adana Hattındaki Şehirsel Büyümenin Mekânsal Etkileri
}

\section{Spatial Impacts of Urban Growth on the Mersin, Tarsus, and Adana Lines}

\author{
Selin YILDIZ GÖRENTAŞ ${ }^{1}$ (D), Sevil SARGIN² (1) \\ ${ }^{1}$ Arş. Gör., Kilis 7 Aralık Üniversitesi, Fen Edebiyat Fakültesi, Coğrafya Bölümü, Kilis, Türkiye \\ ${ }^{2}$ Prof. Dr., Marmara Üniversitesi, Fen Edebiyat Fakültesi, Coğrafya Bölümü, İstanbul, Türkiye
}

ORCID: S.Y.G. 0000-0001-5497-0967; S.S. 0000-0003-3402-4660

\section{öz}

Şehirlerin büyümesiyle birlikte şehir alanlarındaki arazi örtüsü ve kullanımı değişimi de hızlanmaktadır. Bu nedenle, dinamik ve karmaşık bir yapıya sahip olan şehir yerleşmelerinde mekanın insan ve faaliyetleri tarafından işgal edilmesi sonucunda doğal kaynakların aşırı tüketimi, çevresel sorunlar, arazinin plansız ve yanlış kullanımı gibi sorunlar ortaya çıkmaktadır. Bu çalışmada, Türkiye'nin birleşik şehirsel alanlarından biri olan Mersin, Tarsus ve Adana hattındaki şehirleşmenin 1989 yılından 2019 yılına kadar meydana getirdiği mekânsal değişimi arazi örtüsü ve kullanımı bağlamında ortaya koymak, şehirsel büyümenin yayılış yönünü belirlemek ve bu değişim/dönüşüme neden olan mekânsal dinamikleri incelemek amaçlanmıştır. Buna yönelik olarak, yaklaşık son 30 yılı kapsayacak şekilde temin edilen 6 farklı Landsat uydu görüntüleri kontrollü sınıflandırma yöntemiyle sınıflandırılarak doğruluk analizleri gerçekleştirilmiştir. Üretilen arazi örtüsü/kullanımı haritaları sonucunda çalışma alanındaki şehirlerin genellikle merkezden çevreye ve kuzeye doğru büyüdüğü ve aynı zamanda Mersin-Adana karayolu üzerinde çizgisel hat boyunca yayılış gösterdikleri görülmüștür. Buna ilaveten 1989 ile 2019 yılları arasındaki 30 yıllık süreçte şehir alanları 16.782 ha artış ile mevcut alanını ikiye katlamıştır. Şehirsel büyümenin genellikle tarım alanları ve yarı doğal alanlar üzerinde gelişmesi ve ileriye yönelik yapılan projelerle gelecekte de bu alanların tahrip edileceğinin bilinmesi mekânsal tüketimin en net göstergesidir.

Anahtar kelimeler: Mekânsal değişim, Şehirsel büyüme, Arazi örtüsü/arazi kullanımı

\section{ABSTRACT}

Changes in land covers and land use are increasing along with the growth of cities. Therefore, problems such as overconsumption and exploitation of natural resources, environmental pollution, and unplanned and improper use of the land because of occupation of the space by people and their activities in urban settlements, which have a dynamic and complex structure. This study aims to explore the urbanization line between Mersin, Tarsus, and Adana, which is one of Turkey's conurbations, to reveal the spatial changes in the context of land cover and use from 1989 to 2019; determine the direction of urban sprawl; and investigate the spatial dynamics causing these changes and conversions. In this study, six different Landsat satellite images from the last 30 years were classified using a supervised classification method, and then accuracy assessments were carried out. The results revealed that urban areas have been growing from their centers to peripheries, mainly northwards and along the linear line on the Mersin-Adana highway. Additionally, the urban areas had doubled their existing area with an increase of 16.782 hectares in the 30-year period between 1989 and 2019. The urban areas have been sprawling on agricultural lands and seminatural areas, and current projects indicate that more such areas will be destroyed in the future. All these are clear indicators of spatial consumption in the study area.

Keywords: Spatial change, Urban growth, Land cover/land use

Başvuru/Submitted: 11.05.2021 • Revizyon Talebi/Revision Requested: 20.06.2021 • Son Revizyon/Last Revision Received: 03.07 .2021 • Kabul/Accepted: 25.10 .2021

Sorumlu yazar/Corresponding author: Selin YILDIZ GÖRENTAŞ / syildiz@kilis.edu.tr Atıf/Citation: Yildiz Gorentas, S., \& Sargin, S. (2021). Mersin, Tarsus ve Adana hattındaki şehirsel büyümenin mekânsal etkileri. Cografya Dergisi, 43, 127-142. https://doi.org/10.26650/JGEOG2021-936379 


\section{EXTENDED ABSTRACT}

The continuous increase in the world's urban population is an indicator that spatial pressure will also increase at the same rate. Along with the urbanization processes, the space requirement of the increasing population causes urban landscape changes over time, leading to other land-use changes. These changes further lead to overconsumption and exploitation of natural resources, environmental pollution, and unplanned and improper use of the land. Overpopulation in urban areas has been causing spatial changes and land-use changes by sprawling toward their peripheries over time. Remote Sensing and Geographical Information Systems technologies facilitate the analyses of spatial changes and conversions in urban areas, which are quite dynamic and complex settlements. This study aims to explore the urbanization line between Mersin, Tarsus, and Adana, which is one of Turkey's conurbations, to reveal the spatial changes in the context of land cover and use from 1989 to 2019, determine the direction of urban sprawl, and investigate the spatial dynamics causing these changes and conversions.

This study has used the satellite images of 1989, 1995, 2001, and 2007 from Landsat 4-5 TM sensor and the images of 2013 and 2019 from the Landsat 8 OLI sensor. Thus, in this study, the 30 -year period in total has been analyzed. The data analyses process has been divided into three stages: preliminary preparation, classification, and accuracy assessment. The preliminary preparation process, which is the first methodological step of the study, involves the standardization of the satellite data with various sensors and bands for classification. In the second stage, the training data sets are defined by taking the CORINE land cover system as a reference source because of the segmentation process. Next, a supervised classification procedure is applied to each Landsat satellite image by using the Maximum Likelihood technique. Thus, the land cover and land-use maps of 1989, 1995, 2001, 2007, 2013, and 2019 are produced. In the last stage, accuracy assessment analyses are carried out using the stratified random sampling technique. Therefore, the study achieved above $90 \%$ overall accuracy rates and about $85 \%$ Kappa values.

The findings revealed that the only land-use class that has continuously expanded in the last 30 -year period is the artificial areas, whereas the other classes have fluctuated during this period. Artificial areas, which constituted 1.6\% (11.600 ha) of the study area in 1989, expanded spatially and reached 3.8\% (28.382 ha) of the area in 2019. This shows how steadily the urban growth has been in this conurbation area over the years. In continuation with the trend, the cities are expected to sprawl further, and their built-up area will increase. Although the agricultural land class, which covers the largest part of the study area, follows a fluctuating course with increase and decrease in the last 30 years, this land class corresponds to approximately half of the study area today with a total area of 61.280 ha. The forest areas, which reflect a similar pattern, have also expanded spatially during this 30 -year period from $3.6 \%$ to $7.6 \%$ in the study area, increasing by 29.713 ha in total. The findings also reveal that no significant changes occurred in the water bodies, which is the second-largest land cover class in the study area. According to the results, seminatural areas and wetlands are the land cover and use classes that decreased spatially between 1989 and 2019.

The study revealed that urban areas have been growing from their centers to peripheries, northwards, and linearly along the MersinAdana highway, connecting and merging the three cities since 1989. The main spatial dynamics causing these changes and conversions include main transportation systems, industrial and commercial areas, social and cultural facilities, and regional attraction centers. This situation clearly shows how the increasing relations and interactions between these three cities reflect in the space and shape the space. The study revealed that 8.811 hectares of agricultural land is used for urban development that clearly shows the extent of spatial consumptions and destruction. The current projects in the region show that the problem of misuse of agricultural lands will continue in the future. Some national and international projects are on the best and most versatile agricultural lands (grades 1, 2, and 3). The conversion of agricultural lands to urban lands, which shapes and controls the region's economy to a great extent, threatens spatial sustainability. Therefore, it can be suggested that northward urban growth in seminatural areas will be more beneficial for protecting agricultural lands and environment. 


\section{GİRIŞ}

Dünya nüfusunun 1950 y1lında \%29,6'sın1, günümüzde ise $\% 56,2$ 'sini bünyesinde barındıran şehirlerin 2050 yılında toplam nüfus içindeki oranının $\% 68,4$ olacağı tahmin edilmektedir (UN, 2018). Bu durum; ekonomik, sosyal ve kültürel gibi birçok alanda hayatın kontrol edildiği şehir yerleşmelerindeki nüfus tarafından mekanda yaratılan baskının geçmişten günümüze sürekli arttığının ve ilerleyen dönemlerde de artmaya devam edeceğinin bir göstergesidir (Buhaug ve Urdal, 2013). Artan nüfusun mekan gereksinimi şehirlerin fiziksel görünümünün değişmesine ve özellikle çevrelerine doğru büyüyerek farklı amaçlarla kullanılan arazilerin dönüşmesine sebep olmaktadır (Fang ve Wang, 2013). Söz konusu mekânsal değişim ve dönüşüm beraberinde doğal kaynakların aşırı tüketimi, çevresel sorunların sürdürülebilirliği tehdit etmesi, arazinin plansız ve kontrolsüz kullanımı, nüfusun ihtiyaç duyduğu hizmetlerin yetersizliği gibi birçok sorunu gündeme getirmektedir.

Sanayi Devrimi ile şehirlerdeki nüfus birikimi ve 'şehir' olarak tanımlanan yerleşmelerin sayısındaki artışı ifade eden şehirleşme olgusu dünyada olduğu gibi Türkiye'de de 1950'li yıllardan itibaren etkilerini hissettirmektedir (Keleş, 2017; Tümertekin, 1973; Yüceşahin, Bayar ve Özgür, 2004). Yeni dönemin gerektirdiği ekonomik yenilenme şehirlerin yapısal ve mekânsal olarak değişmesini hızlandırmıştır (Tekeli, 1998). Böylece toprağa bağlı ekonomik faaliyetlerle geçimini sağlayan yerleşmelerin yerini modern sanayinin hüküm sürdüğü gelişmiş şehirler almıştır. Özellikle 1950'li yıllardan beri süregelen nüfusun şehirlere doğru hareketi sonucunda Türkiye'nin baskın yerleşme dokusu değişmiştir. Devlet İstatistik Enstitüsü (DİE) (1927-2000) ve Türkiye İstatistik Kurumu (TÜİK) (2000-2020) nüfus verilerine göre şehirlerde yaşayan nüfusun toplam nüfus içindeki oranı 1927 yılında \%24,2 iken, 1985 yılında \%53'e, günümüzde ise \%92,7'ye ulaşmıştır. Günümüzde oldukça yüksek orana sahip olan şehir nüfusu; 2012 yllında yayınlanan yasa gereği büyükşshir belediyelerine bağlı tüm köyleri mahalle olarak kabul edilmesiyle ortaya çıkmaktadır (Resmi Gazete, 2012). Fakat bu durum fonksiyonel olarak kırsal karaktere sahip yerleşim yerlerinde yaşayan nüfusun şehir nüfusu içinde değerlendirilmesine sebep olmuştur. Türkiye'de toplam nüfus içinde en çok paya sahip olan kır nüfusu ilk defa 1985 yılında baskın nüfus yapısını şehirlere bırakmıştır. Tarımda makineleşmeyle insan gücüne ihtiyacın azalması ve sanayileşme faaliyetlerinin etkinliğinin artmasıyla tetiklenen şehirleşme süreci (Avc1, 1993), kalkınma planlarının şehir yönündeki özendirici politikaları, çeşitli yasal düzenlemeler, üniversitelerin kuruluşu, güvenlik kaygısı ve sosyal imkanlar gibi farklı nedenlerle günümüzdeki rekor seviyesine ulaşmıștır (Keleş, 2017; Sargın, 2007).

Türkiye'de şehirleşme her ne kadar demografik bir değişim sürecini ifade etse de (Bazin ve de Tapia, 2015), bu durum aynı zamanda şehir alanlarındaki mekânsal dönüşümün de bir yansımasını sunmaktadır. Böylece şehirlerin çevrelerine doğru geçmişten günümüze devam eden mekânsal büyümesi şehirlerin birbirleriyle etkileșimini arttırarak farklı mekânsal örüntülerin meydana gelmesine sebep olmuştur. Buna göre, şehirsel nüfusun sürekli bir mekânsal kuşak oluşturduğu birleşik şehirler (konürbasyon) ortaya çıkmaktadır (Yüceşahin vd., 2004). İstanbul, Ankara, İzmir ve Adana şehirleri ile çevreleri ülkemizin başlıca şehirsel birleşik kuşakları olarak bilinmektedir (Hayır Kanat, 2016).

Gelişen uydu teknolojileriyle birlikte mekanı konu edinen birçok farklı disiplinde ve alanda kullanılan Uzaktan Algılama ve Coğrafi Bilgi Sistemleri; şehir alanlarındaki arazi kullanımı değişiminin analiz edilmesinde de uygulanarak doğru ve güvenilir sonuçların elde edilmesini sağlamaktadır. Bu sayede oldukça geniş alanları kapsayan ve karmaşık bir yapıya sahip olan şehirlerin arazi kullanımı hakkında daha net bilgilere ulaşılabilmektedir. Mekânsal analiz yöntemlerinin gelişmesi ve çeşitlenmesiyle birlikte şehirleşmenin mekânsal etki ve sonuçlarını konu edinen birçok araştırma insan ve faaliyetlerinin mekanı nasıl işgal edip dönüştürdüğünü ortaya koymaktadır (Bayar ve Karabacak, 2017; Belal ve Moghanm, 2011; Cengiz, Çavuş ve Koç, 2014; Döker ve Gül, 2019; Ishtiaque, Shrestha ve Chhetri, 2017; Kaya ve Toroğlu, 2015; Kumar, Pathan ve Bhanderi, 2007; Maktav ve Erbek, 2005; Mundia ve Aniya, 2005; Olğaç ve Doğan, 2020; Wu, Li ve Yu, 2016). Şehirsel alanlarda meydana gelen alansal büyümenin tarım arazileri ile ormanlık alanlar üzerinde gerçekleștiği ve bu durumun mekânsal sürdürülebilirlik odaklı yönetim süreçlerini olumsuz etkilediği bilinmektedir. Ayrıca şehirlerin mekan üzerindeki kontrolsüz ve plansız gelişimi ve yanlış arazi kullanımı beraberinde ciddi çevresel sorunlara ve kayıplara yol açabilir (Açıksöz, Topay ve Y1lmaz, 2008; Bayrakdar, Döker ve Keserci, 2020; Özdemir ve Bayrakdar, 2007; Yiğitbaşığlu ve Uğur, 2010). Böylece oldukça dinamik ve karmaşık olan şehirsel gelişimin mekânsal yayılımının veya tüketiminin gözlemlenmesi ihtiyacı ortaya çıkmaktadır. Bu çalışmada şehirsel yığılma alanlarından biri olan Mersin, Tarsus ve Adana hattındaki şehirleşmenin geçmişten günümüze meydana getirdiği mekânsal değişimi arazi örtüsü ve kullanımı bağlamında ortaya koymak, şehirsel büyümenin yayılış yönünü belirlemek ve bu değişim/dönüşüme neden olan mekânsal dinamikleri incelemek amaçlanmaktadır. Buna yönelik 
olarak çalışma alanındaki şehirlerin mekânsal gelişim ve arazi kullanımı üzerindeki değişim süreçlerini inceleyen birçok çalışma olsa da (Alphan, 2003; Beyhan, Taubenböck, Suffa, Ullmann, Rauh ve Dech, 2012; Gülersoy, Çelik ve Sönmez, 2014; Sandal ve Gürbüz, 2003; Sönmez, 2011), birden fazla şehrin içinde bulunduğu birleşik şehirlerin yarattığ mekânsal dönüşümü konu edinen araştırma eksikliği göze çarpmaktadır. Ayrıca bu çalışma, bölgenin en önemli ekonomik kaynaklarından biri olan tarım alanlarının amaç dışı kullanılması, şehirsel büyümenin yarattığı arazi örtüsü ve kullanımı değişimleri ve şehirsel büyümenin mevcut şekliyle devam etmesi halinde ortaya çıkabilecek sorunları eleştirel bir yaklaşımla değerlendirmektedir.

\section{1. Çalışma Alanı}

Şehir bileşenlerinin belirsiz sınırlara sahip olması, çalışma alanı belirlenirken idari sınır gibi fiziksel ve sosyal anlamda coğrafi mekan birimlerinin sürekliliğini bozan ölçütler yerine mekânsal dinamikleri dikkate alan insan deneyimlerinin göz önünde bulundurulması gerekliliğinin ön plana çıkmasına sebep olmaktadır (Campari, 1996). Bu nedenle dinamik olan şehirsel gelişimin mekânsal değişimi ortaya koymak için herhangi bir idari sınırın alan kısıtlamasına yol açmaması ve şehirsel yapıların mekânsal sürekliliğini bozmaması temel alınmıştır. Mekansal olarak bütünlüğün korunması açısından Mersin, Tarsus ve Adana şehirleri odak kabul edilerek ve günümüzdeki şehir alanının mekânsal sürekliliği dikkate alınarak çalışma alanı ve sınırları belirlenmiştir.

Türkiye'nin güneyinde ve Akdeniz Bölgesi'nin doğu kesimindeki Adana Bölümü'nde yer alan çalışma alanı yaklaşık olarak $7.453 \mathrm{~km}^{2}$ alan kaplamaktadır. Bölgenin kuzeybatısında Batı Torosların uzantısı olan yüksek ve engebeli dağlık kütleye rağmen çalışma alanı genellikle düz veya düze yakın bir arazi yapısına sahiptir (Şekil 1). Türkiye'nin en geniş ve tarımsal potansiyeli yüksek ovalarından biri olan ve çalışma sahasının büyük bir bölümünü oluşturan Çukurova, Ceyhan ve Seyhan Nehri ile Tarsus Çayı'nın taşıyıp biriktirdiği materyallerin oluşturduğu alüvyon sahasıdır (Biricik ve Kurt, 1998). Genellikle kuzeyden güneye doğru akarak Akdeniz'e ulaşan bu ana akarsuların oluşturduğu kıyı ovası batıda Mersin şehrinde dar bir alana karşılık gelir ve doğuya doğru genişleyerek Tarsus, Seyhan ve Ceyhan Nehirlerinin delta sahalariyla son bulur (Göney, 1976). Böylece su varlığı bakımından oldukça elverişli olan ve batıdaki dağlık kesime nazaran düzlük ova arazisi üzerinde bulunan bölge geçmişten beri nüfusun çekim merkezi konumundadır. Buna ilaveten, çevrelerindeki önemli merkezlere olan yakınlıkları, otoyol, karayolu ve demiryolunun şehirlerin paralelinde uzanıyor olması, Mersin Limanı, havaalanlarının sağladığı lojistik avantaj, çok sayıdaki sanayi kuruluşunun faaliyetleri ve sosyal olanaklar nedeniyle birbirlerine oldukça yakın olan ve üç şehrin içinde bulunduğu çalışma alanı

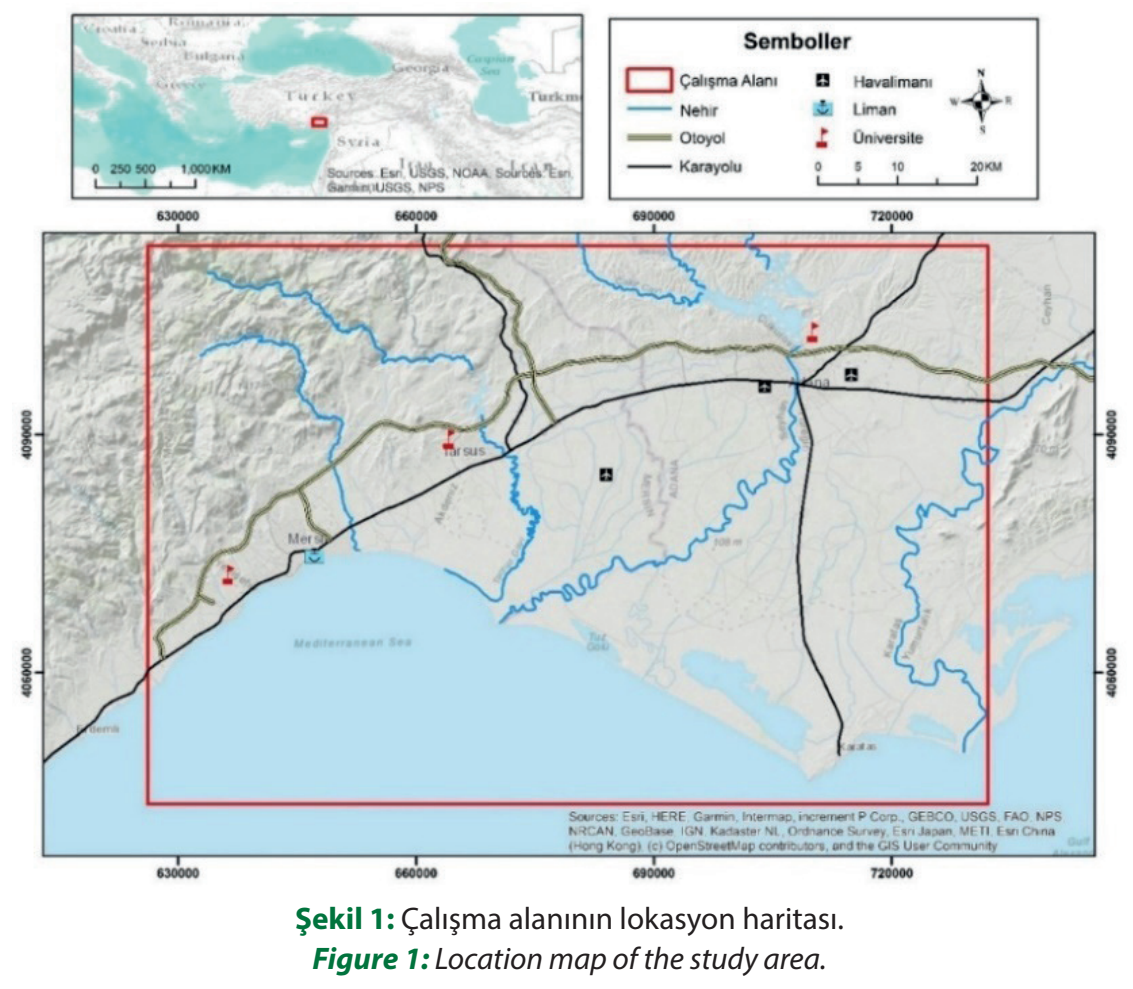


Türkiye'nin birleşik şehirsel alanlarından birini oluşturmaktadır. Günümüzde yaklaşık olarak 3,2 milyon nüfusu bünyesinde barındıran çalışma alanındaki şehirler farklı idari birimleri meydana getirmektedir.

\section{VERİ VE YÖNTEM}

Geçmişten günümüze meydana gelen arazi örtüsü ve kullanımı değişimlerinin tespit edilmesi için çalışma alanına karşılık gelen 30 metre yersel çözünürlüğe sahip Landsat uydu görüntüleri ABD Jeoloji Servisi olan USGS (United States Geological Survey) üzerinden temin edilmiştir (USGS, 2020). Toplamda 30 yıllık sürecin analiz edildiği çalışmada Landsat 4-5 TM sensöründen 1989, 1995, 2001, 2007 y1lları; Landsat 8 OLI sensöründen 2013 ve 2019 yıllarına ait uydu görüntüleri elde edilmiştir. Uydu verileri temin edilirken zaman aralığı sabitliğine (6 yıl aralıklı) ve görüntü netliğine dikkat edilmiştir (Tablo 1). Çalışma alanı ve sınırları iki ayrı paftada yer aldığından dolayı her bir yıl için iki ayrı uydu görüntüsüne yani toplamda 6 yıl için 12 uydu görüntüsüne ulaşılmıştır. Ayrıca çalışmanın doğruluk analizinin gerçekleştirilmesinde referans olarak temin edilen farklı yıllara ait veriler kullanılmıştır. Bunlar; Harita Genel Müdürlüğü (HGM) 1/25.000'lik topografya haritaları, bölgedeki yerel yönetimlerden alınan imar planları ve hava fotoğraflarından oluşmaktadır.

Veri analizi; ön hazırlık, sınıflandırma ve doğruluk analizi olmak üzere üç aşamalı olarak gerçekleştirilmiştir (Şekil 2). Çalışmanın metodolojik anlamdaki ilk aşaması olan ön hazırlık süreci farklı sensörler ve bantlardan oluşan uydu verilerinin sinıflandırma yapmak için uygun ve standart duruma getirilmesi adımlarından oluşmaktadır. İlk aşamada sınıflandırmaya hazır hale getirilen uydu görüntüleri ikinci aşamada sınıflandırılarak arazi örtüsü/kullanımı haritalarının üretilmesiyle sonuçlanmaktadır. Elde edilen haritaların gerçeğe uygunluk derecesini ifade eden doğruluk analizi aşaması ise çalışmadaki veri analizinin son adımını oluşturur.

\section{1. Ön Hazırlık}

Ön hazırlık aşaması; veri dönüşümü, pafta birleştirme, kesme, bant kombinasyonu ve hücre bölünmesi olmak üzere beş temel adımdan meydana gelmektedir. İlk adımda uydu görüntülerinin veri uzantıları dönüştürülmüştür. Çalışma alanı iki ayrı paftada yer aldığı için, her bir yıla ait aynı aralıktaki bantlar tek bir görüntü olarak birleştirilmiştir. Örneğin; 2019

Tablo 1: Uydu görüntülerinin özellikleri.

Table 1: Characteristics of satellite images.

\begin{tabular}{|c|c|c|c|c|c|c|}
\hline & 1989 & 1995 & 2001 & 2007 & 2013 & 2019 \\
\hline Görüntü Tarihi & 25.07 .1989 & 12.09 .1995 & 10.07.2001 & 25.06 .2007 & 13.09 .2013 & 26.06 .2019 \\
\hline Uydu Sensörü & LANDSAT 4-5 TM & LANDSAT 4-5 TM & LANDSAT 4-5 TM & LANDSAT 4-5 TM & LANDSAT 8 OLI/TIRS & LANDSAT 8 OLI/TIRS \\
\hline
\end{tabular}

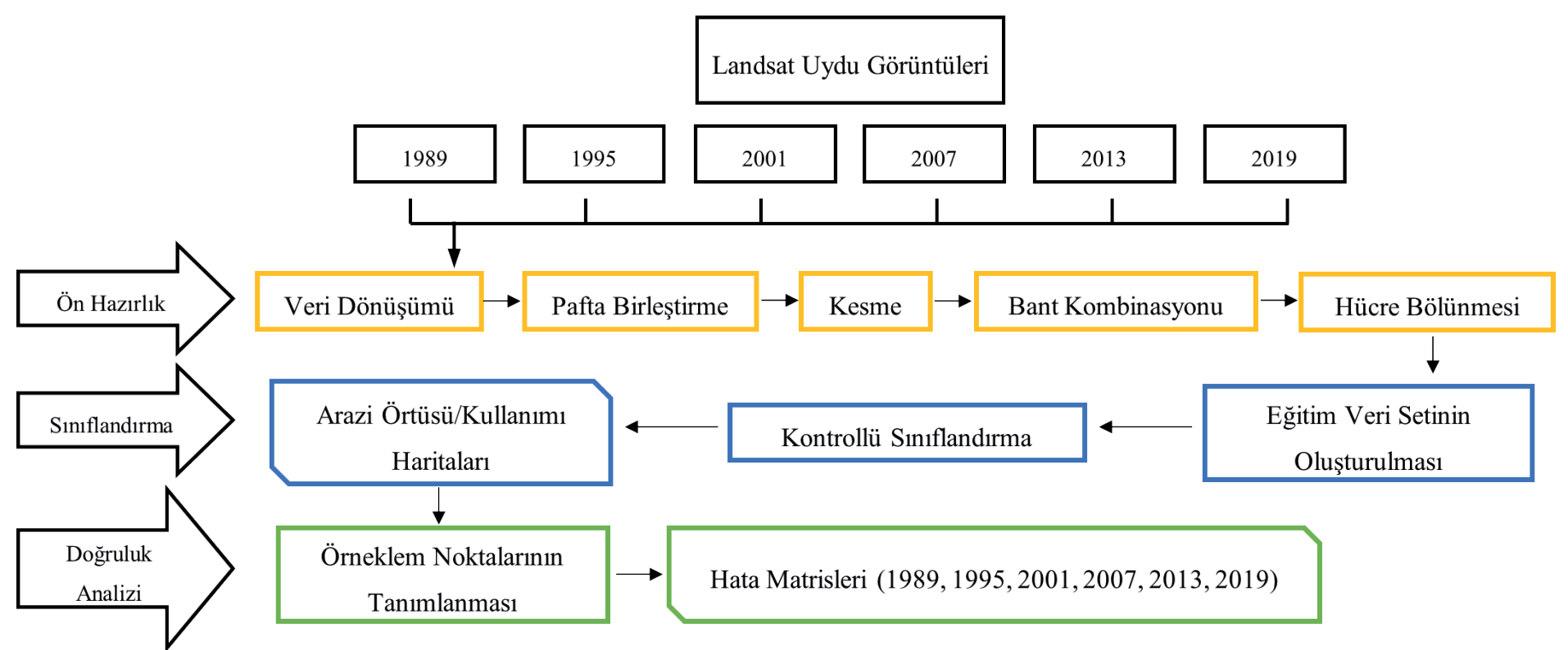

Şekil 2: Analiz akış şeması.

Figure 2: Analysis flow chart. 
yılına ait kuzey paftanın 1 . bandı ile güney paftanın 1. bandı birleştirilerek 2019 yılının 1. bandını temsil eden tek bir pafta elde edilmiştir. $\mathrm{Bu}$ işlem her bir yıl ve bant için ayrı ayrı uygulanmıştır. Ardından mozaiklenen her bir bant çalışma alanı sınırından kesilmiştir (Şekil 3). Bant kombinasyonu işlemi için arazideki detayların daha net görüntülenmesine ve bitki örtüsü, toprak, su ve tarım alanlarının daha net ayırt edilmesine olanak tanıyan sahte renk bant kombinasyonu tercih edilmiş̧ir (Horning, 2004). Böylece LANDSAT 4-5 TM uydu sensörüne sahip uydu görüntüleri için (1989, 1995, 2001, 2007 y1lları) 5,4,3 (RGBRed, Green, Blue); LANDSAT 8 OLI uydu sensörüne sahip uydu görüntüleri için (2013 ve 2019 yılları) 6,5,4 (RGB) bantları kullanılarak bant kombinasyonu uygulanmıştır.

Ön hazırlık sürecinin son adımı olan hücre bölünmesi (segmentasyon) işlemi, uydu görüntülerindeki piksellerin spektral benzerliklerine göre homojen olarak gruplandırılması anlamina gelmektedir (Eastman, 2016). Bu sayede birbirleriyle benzer yansıma özelliğine sahip hücre grupları olan segmentlerin kullanıcı tarafından en uygun arazi örtüsü ve kullanımı sınıfına atanması daha kolay olmaktadır. Böylece ön hazırlık süreci tamamlanarak uydu görüntüleri sınıflandırmaya hazır hale getirilmiştir.

Uydu görüntülerinin sınıflandırılması aşamasına geçmeden önce, analizde hangi arazi örtüsü ve kullanımı sınıflarının kullanılacağının belirlenmesi gerekmektedir. Çalışmanın arazi örtüsü ve kullanımı sınıfları CORINE referans sisteminin birinci düzeyi baz alınarak oluşturulmuştur. Buna göre yapay alanlar, tarım alanları, orman alanları, yarı doğal alanlar, sulak alanlar ve su kütleleri olmak üzere 6 arazi örtüsü ve kullanımı sınıfı ile bu sınıfların arazide temsil ettiği alanlar tanımlanmıştır (Tablo 2). Arazi örtüsü/kullanımı sınıflarının mekanda temsil ettikleri alanlar bölgeden bölgeye değişiklik göstereceği için hangi sınıfın hangi mekânsal üniteleri ifade ettiğinin bilinmesi önem arz etmektedir. Buna göre, Mersin, Tarsus ve Adana şehirlerini içeren çalışma alanındaki arazi örtüsü/kullanımı sınıflarının mekanda karşılık geldikleri birimler tanımlanmıştır.

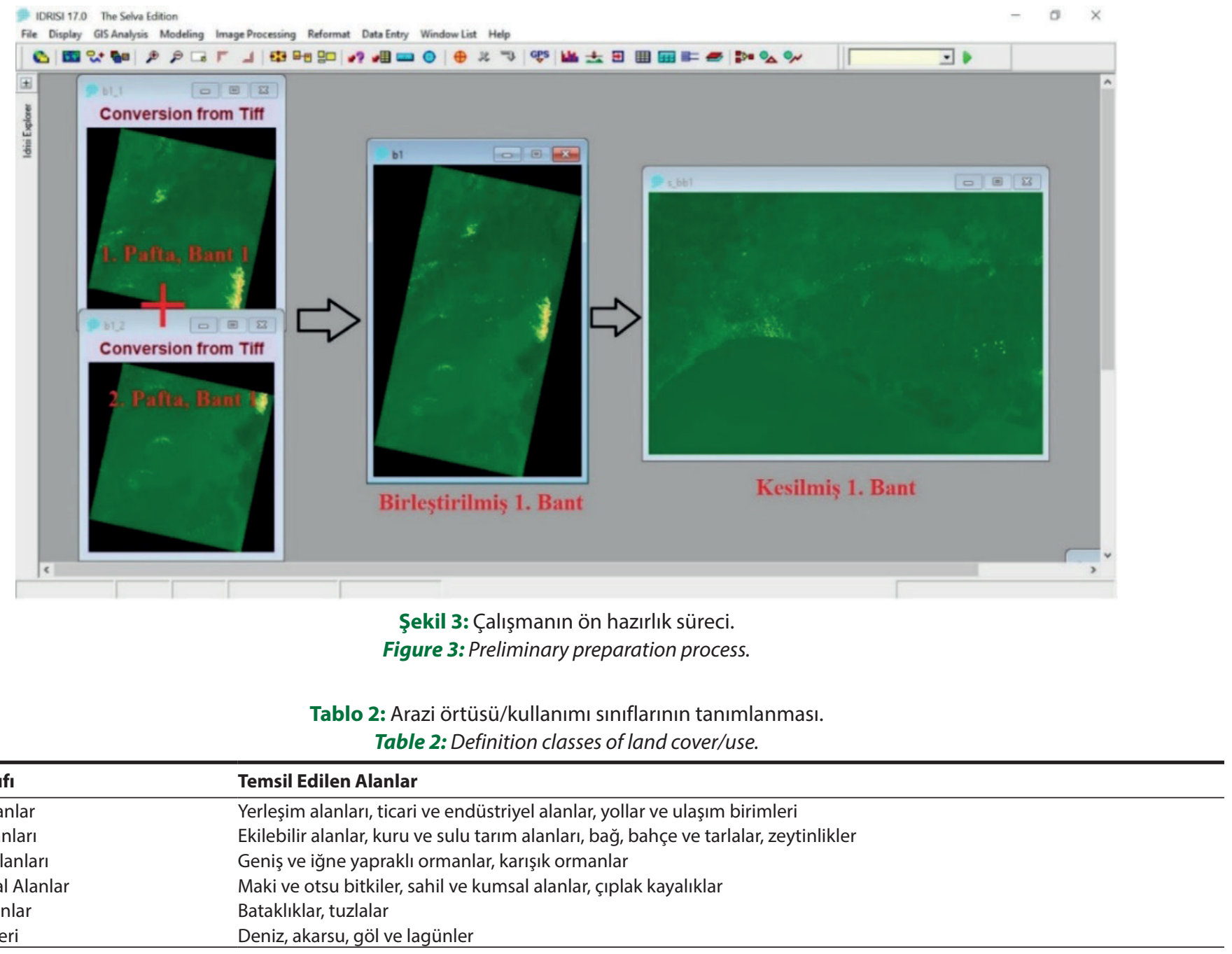




\subsection{Sinıflandırma}

Veri analizinin ikinci aşaması olan sınıflandırma süreci; eğitim veri setinin oluşturulması ve kontrollü sınıflandırma adımlarından oluşmaktadır. Segmentasyon işlemi sonrası her bir uydu görüntüsü üzerinde piksellerin hangi arazi örtüsü/kullanıma sınıfına ait olduğunu ifade eden örneklem alanlar tanımlanmıştır (Şekil 4). Oluşturulan veri setlerindeki toplam örneklem alanların sayısı; 1989 yılı için 620, 1995 yılı için 735, 2001 y1lı için 680, 2007 y1lı için 880, 2013 y1lı için 540, 2019 yılı için 830 'dur. Çalışma alanının oldukça geniş bir alanı kaplaması ve segmentlerin yoğunluğu veri setlerine tanımlanan örneklem alanlarının sayıca fazla olmasinın ana sebepleri arasında gösterilebilir.

Kullanıcı tarafindan uydu görüntüsü üzerinde belli arazi örtüsü ve kullanımı sınıfına tanımlanan pikseller belli bir yansıma aralığında gruplandırılarak uygun sınıfa atanmış olur. Bunun sonucunda bilinen benzer örneklerin kullanılarak bilinmeyen benzer piksellerin sınıflandırılmasını ifade eden kontrollü sınıflandırma işlemi uygulanır (Campbell ve Wynne, 2011). Maksimum Benzerlik (Maximum Likelihood) tekniği örnek alınan alanların ortalama ve varyans değerlerini kullanarak, her bir sınıfa ait piksellerin olasılığını hesaplayan bir kontrollü sinıflandırma yöntemidir (Eastman, 2016). Buna göre eğitim veri setleri tanımlanan her bir Landsat uydu görüntüsüne Maksimum Benzerlik tekniği ile kontrollü sınıflandırma işlemi yapılmıştır. Böylece 1989, 1995, 2001, 2007, 2013 ve 2019 yıllarına ait arazi örtüsü/kullanımı haritaları üretilmiştir. Sınıflandırma sonrası görüntü üzerindeki bazı pikseller, kendisini çevreleyen piksellerden farklı sınıfa dahil olarak izole edilmiş olabilir (Ahmed ve Ahmed, 2012). Bu izole piksellerin kaldırılarak görüntünün genelleştirilmesi için filtreleme işlemi uygulanır. Bu çalışmada arazi örtüsü ve kullanımı haritaları mod filtresinin $5 * 5$ şablonuna göre filtrelenmiştir. Mod filtresi, her pikselin kendisini çevreleyen 24 pikseldeki $(5 * 5)$ çoğunluk durumunda olan sınıfla değiştirilmesi esasına dayanmaktadır (Eastman, 2009). Üretilen arazi örtüsü/kullanımı haritalarına uygulanan filtreleme işlemi sonucunda mekânsal olarak daha net sonuçlara ulaşılmıştır.

\subsection{Doğruluk Analizi}

Veri analizini son aşaması olan doğruluk analizi, üretilen arazi örtüsü ve kullanımı haritalarının gerçeği yansıtma derecesini yani her bir yıla ait sınıflandırılmış haritanın, ait olduğu yıldaki gerçek arazi örtüsü ve kullanımı sınıflarına benzerlik oranını temsil etmektedir. Doğruluk analizi yapılırken örneklem alanlarının tanımlanmasında farklı tarihlere ait referans haritaları (imar planları, topografya haritaları ve hava fotoğrafları) altlık olarak kullanılmıştır. Ayrıca arazi çalışmalarıyla 62 koordinat noktası alınmış ve böylece günümüzdeki gerçek arazi örtüsü ve kullanımı sınıfları örneklem alanlar aracılığıyla tanımlanmıştır.

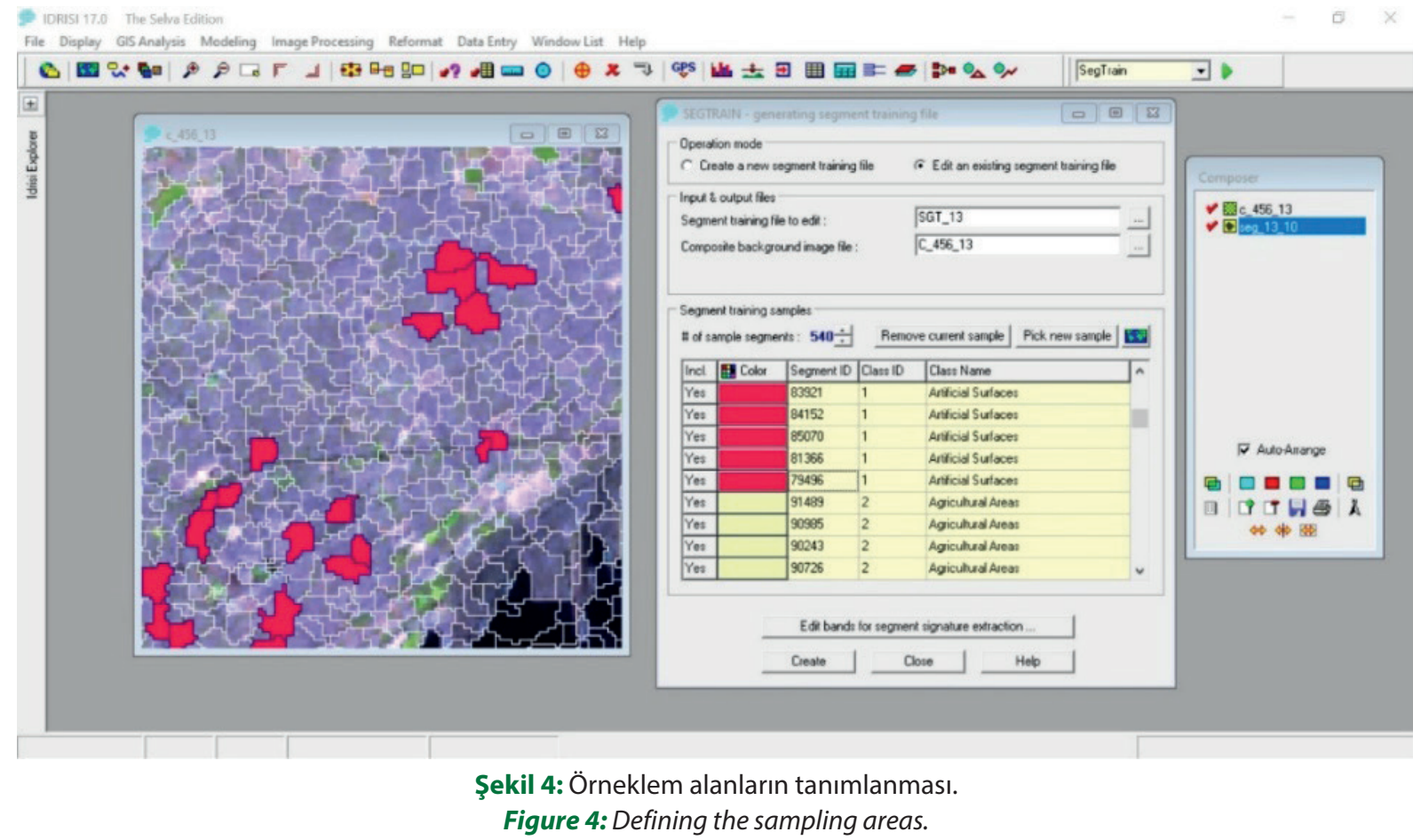


Doğruluk analizinin yapılması için harita üzerine nokta atılarak gerçek ve sınıflandırılmış arazi örtüsü ve kullanımı sınıflarının karşılaştıılması yapılmaktadır. Bunun için basit rastsal, sistematik ve tabakalı rastsal olmak üzere 3 farklı örnekleme yöntemi kullanılır. Basit rastsal örnekleme yöntemine göre evreni oluşturan her bir birim eşit derecede örneklem olarak seçilme olasılığı taşımaktadır (Franklin ve Walker, 2010). Sistematik örneklemede örneklem alınacak birimler 'örneklem aralığı' adı verilen belli bir kural dahilinde sistematik bir şekilde belirlenir (Jensen ve Shumway, 2010; Yavan, 2014). Basit rastsal ve sistematik örnekleme yöntemleri evrenin homojen olduğu durumlarda uygun olmaktadır (Lo, 2009). Fakat mekânsal uygulamalarda çalışma evreni birbirinden farklı unsurlardan oluşan heterojen bir yapıya sahip olduğu için genellikle tabakalı rastsal örnekleme yöntemi kullanılmaktadır (Yavan, 2014). Bu örnekleme yönteminde ise, evreni oluşturan her bir gruptan belli oranda bağımsız örnekler alınmaktadır (Franklin ve Walker, 2010). Bu çalışmada tabakalı rastsal örnekleme yöntemi kullanılarak arazi örtüsü ve kullanımı sınıfları örneklem grupları olacak şekilde her bir yıl için 300 adet örneklem noktası atılmıştır. Her bir örneklem noktasının gerçekteki arazi örtüsü ve kullanımı sınıfı referans haritalar dikkate alınarak tanımlanmıştır. $\mathrm{Bu}$ sayede her bir noktanın gerçekteki ve sınıflandırılmış haritadaki arazi örtüsü ve kullanımı sınıfları karşılaştııılarak hata matrislerine ulaşılmıştır.

Hata matrisleri, sınıflandırmanın genel olarak ne kadar doğru olduğunu ve her bir arazi örtüsü ve kullanımı sınıfının tanımlanma sonuçlarının doğruluk oranlarını ortaya koymaktadır. Her bir yıl için yapılan doğruluk analizi sonuçlarına göre kullanıcı doğruluğu, üretici doğruluğu, genel doğruluk ve Kappa istatistiklerine ulaşılmıştır (Tablo 3). Üretici doğruluğu (ihmal hatası) belli bir alanın gerçekte olması gereken sınıfa atanmayarak göz ardı edilmesini; kullanıcı doğruluğu (görev hatası) ise belli bir alanın gerçekte olması gereken sınıftan farklı bir sınıfa atanarak yanılgıya sebep olunduğunu ifade etmektedir (Campbell ve Wynne, 2011; Yener, Koç ve Çoban, 2006). Buna göre doğruluk analizi sonuçları; her bir arazi örtüsü/kullanımı sınıfında kullanıcı ve üretici doğruluklarının oldukça yüksek düzeylerde kaydedildiğini göstermektedir.

Doğru olarak sınıflandırılan piksellerin (çapraz girdiler) bütününe oranını tanımlayan genel doğruluk (Campbell ve Wynne, 2011) değerleri ise her bir yıl için sırasıyla $\% 90, \% 92$, $\% 90, \% 93, \% 92$ ve $\% 94$ olarak hesaplanmıştır. İki harita (sınıflandırılmış ve gerçek arazi örtüsü/kullanımı haritaları) arasındaki şans uyumu ile gerçek uyumun farklılığının ölçülmesi esasına dayanan Khat (Kappa) istatistiğinin formülüne göre Po gözlenen uyum oranını, $\mathrm{Pe}$ ise tesadüfi beklenen uyum oranını temsil etmektedir (Berry, Johnston ve Mielke Jr, 2014). Bu çalışmada gerçekleştirilen doğruluk analizi sonuçlarına göre her bir yılın Kappa değerleri sırasıyla \%84, \%87, \%83, \%89, \%87 ve \%89 oranında kaydedilmiştir.

$$
\kappa=\frac{P_{o}-P_{e}}{1-P_{e}}
$$

Her bir sınıflandırma için yaklaşık \%90'ın üzerinde genel doğruluk oranları ile ortalama $\% 85$ 'in üzerinde Kappa değerlerine ulaşılması sınıflandırmanın güvenilir olduğu sonucunu ortaya koymaktadır.

\section{BULGULAR}

1989, 1995, 2001, 2007, 2013 ve 2019 olmak üzere 6 farklı yıla ait uydu görüntüsünün kontrollü sınıflandırma yöntemiyle analiz edilmesi sonucunda her bir yıla ait arazi örtüsü/kullanımı haritaları elde edilmiştir. Buna göre, 1989 yılından günümüze kadar geçen yaklaşık 30 yıllık süreçte çalışma alanında meydana gelen arazi örtüsü ve kullanımı değişimleri, şehirsel büyüme yönleri ve söz konusu mekânsal dönüşümü yaratan dinamikler tarihsel ve coğrafi bağlamda değerlendirilmiştir.

Tablo 3: Doğruluk analizi sonuçları.

Table 3: Accuracy assessment analysis results.

\begin{tabular}{|c|c|c|c|c|c|c|c|c|c|c|c|c|}
\hline \multirow[b]{2}{*}{ AÖ/AK } & \multicolumn{2}{|c|}{1989} & \multicolumn{2}{|c|}{1995} & \multicolumn{2}{|c|}{2001} & \multicolumn{2}{|c|}{2007} & \multicolumn{2}{|c|}{2013} & \multicolumn{2}{|c|}{2019} \\
\hline & KD & ÜD & KD & ÜD & KD & ÜD & KD & ÜD & KD & ÜD & KD & ÜD \\
\hline 1 & 100 & 86 & 100 & 50 & 100 & 89 & 100 & 88 & 100 & 78 & 100 & 91 \\
\hline 2 & 90 & 89 & 94 & 93 & 89 & 93 & 90 & 98 & 89 & 96 & 93 & 97 \\
\hline 3 & 94 & 83 & 94 & 94 & 100 & 66 & 100 & 76 & 100 & 87 & 96 & 88 \\
\hline 4 & 83 & 82 & 68 & 85 & 61 & 69 & 86 & 71 & 75 & 61 & 78 & 66 \\
\hline 5 & 100 & 80 & 100 & 100 & 67 & 100 & 100 & 100 & 100 & 100 & 100 & 100 \\
\hline 6 & 100 & 99 & 100 & 98 & 100 & 98 & 100 & 100 & 100 & 100 & 100 & 100 \\
\hline GD & \multicolumn{2}{|c|}{90} & \multicolumn{2}{|c|}{92} & \multicolumn{2}{|c|}{90} & \multicolumn{2}{|c|}{93} & \multicolumn{2}{|c|}{92} & \multicolumn{2}{|c|}{94} \\
\hline Kарра & \multicolumn{2}{|c|}{84} & \multicolumn{2}{|c|}{87} & \multicolumn{2}{|c|}{83} & \multicolumn{2}{|c|}{89} & \multicolumn{2}{|c|}{87} & \multicolumn{2}{|c|}{89} \\
\hline
\end{tabular}

AÖ/AK: Arazi Örtüsü/ Kullanımı Sınıfları (1: Yapay Alanlar, 2: Tarım Alanları, 3: Orman Alanları, 4: Yarı Doğal Alanlar, 5: Sulak Alanlar, 6: Su Kütleleri)

KD: Kullanıcı Doğruluğu (\%), ÜD: Üretici Doğruluğu (\%), GD: Genel Doğruluk (\%) 


\subsection{Mekansal Gelişimin İzlenmesi}

1989 yılında çalışma alanının büyük oranda tarım alanları, su kütleleri, yarı doğal alanlar ve orman alanları tarafından baskın olması bölgenin doğal karakterli bir yap1 sergilediğinin göstergesidir (Şekil 5). Toplam 74.5324 ha (hektar) alanın \%44,1'ini kaplayan tarım alanları, çalışma alanının yaklaşık yarısını oluşturmaktadır. Bu durumu meydana getiren temel faktör olarak Çukurova tarım arazilerinin varlığı sayılabilir. Çalışma alanının ikinci en geniş sahasını kaplayan su kütleleri sinıfı (\%27,5) esasen Akdeniz, Berdan Barajı, Seyhan Barajı, bölgenin güney kıyılarından doğusuna doğru uzanan Tuzla Gölü, Akyatan Gölü ve Akyayan Gölü ile temsil edilmektedir. Yarı doğal alanlar bölgenin kuzeyinde ve deniz kıyılarında, orman alanları bölgenin kuzeybatı ve batı kenarında, sulak alanlar ise göl çevrelerinde yoğunluk göstermektedir. Yapay alanlar sınıfı ise 11.600 ha ile bölgenin \%1,6'sını oluşturarak oldukça dar bir
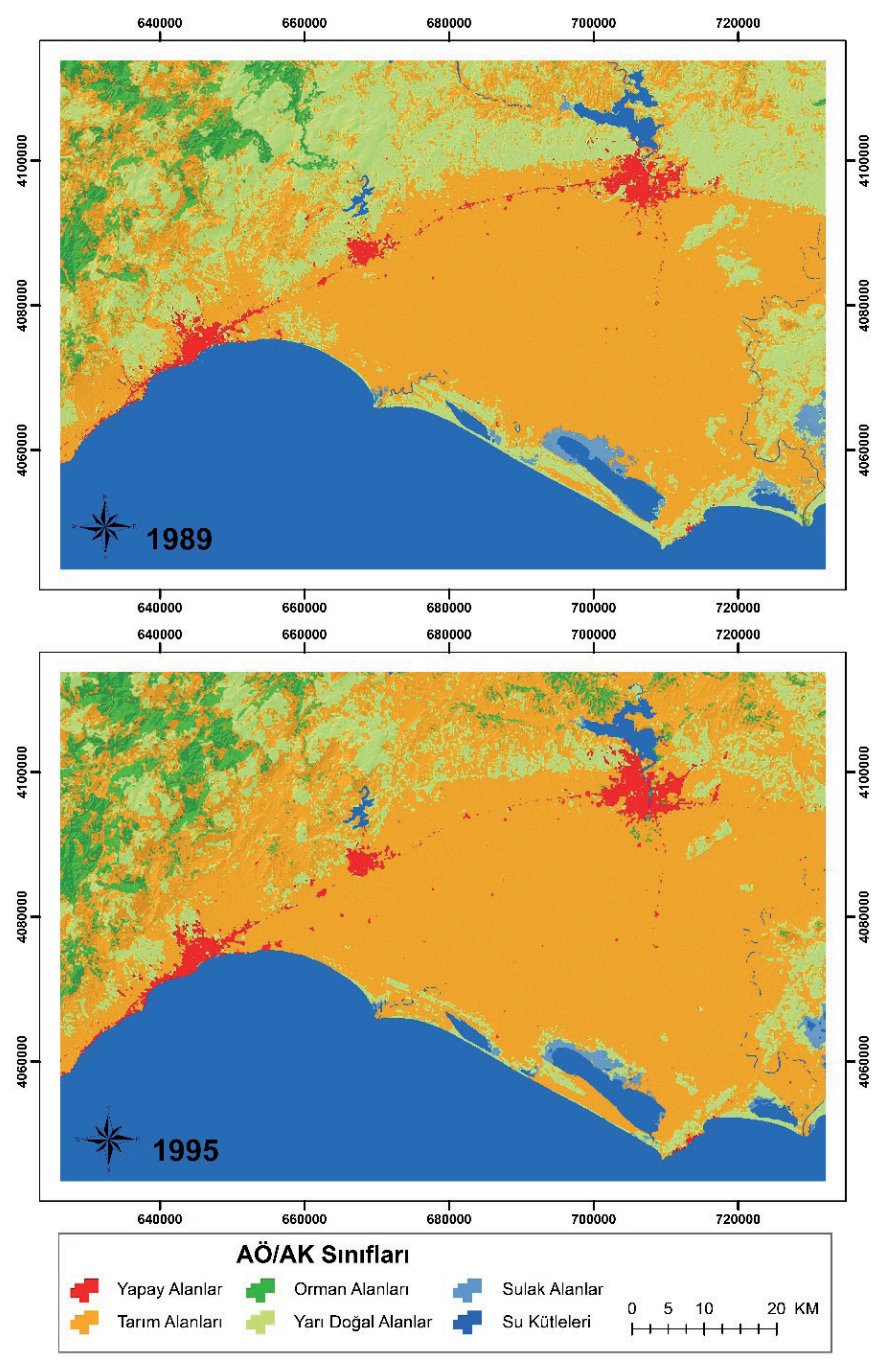

Şekil 5: 1989 ve 1995 yıllarının arazi örtüsü/kullanımı haritaları.

Figure 5: Land cover/use maps of 1989 and 1995. alana karşılık gelmektedir. Bölgenin güneybatısından kuzeydoğusuna doğru yatay düzlemde uzanan ve birbirine Mersin-Adana karayolu (D-400) ile bağlanan Mersin, Tarsus ve Adana şehirleri çalışma alanının nüve niteliğindeki üç ana çekirdek sahasıdır. Türkiye'de kentleşmenin mekandaki yansımalarının 1990'lı yıllardan itibaren daha net fark edildiği göz önünde bulundurulursa, 1989 döneminin bu çalışmadaki şehirleşme sürecinin başlangıç aşamasını ifade ettiği söylenebilir.

1995 yılında bir önceki döneme göre tarım alanları ve orman alanlarında artış, yarı doğal alanlarda azalış meydana gelirken, diğer sınıflar nispeten benzer düzeyde kalmıştır (Şekil 5). Özellikle Adana şehrinin kuzeybatı ile kuzeydoğusunda, Seyhan Barajı'nın batı ve doğusunda ve Mersin-Tarsus karayolunun kuzeyindeki yarı doğal alanların tarım alanlarına dönüştürülmesi söz konusu arazi örtüsü/kullanımı sınıflarının kapladıkları alan bakımından artış-azalış eğilimini göstermektedir. Ayrıca Akyatan Lagünü ile Yumurtalık Lagünü kıyılarındaki bataklık ve mera alanlarının tarımsal faaliyetler amacıyla dönüştürülmesi (Sönmez ve Aytuk, 2014) tarım alanlarının alansal büyümesinin bir başka nedenidir. Bölgenin kuzeybatısı ile kuzeyinde orman alanlarının etkinlik sahasındaki artışın ise 1985-1990 yılları arasında çiplak karstik alanlarda 'Tam Alan Serpme Yöntemi' ile uygulanan Toros Sediri ağaçlandırma çalışmalarından kaynaklandığı söylenebilir (Boydak, 2008). 12.725 ha ile bölgenin \%1,7'sini kaplayan yapay alanlar sınıfının 1989 yılına göre 1.125 ha alan artış kaydederek kuzey yönlü bir gelişim gösterdiği açıkça görülmektedir. Buna ilaveten şehirsel gelişimin üç şehir arasında çizgisel doğrultuda yer alan karayolu boyunca gerçekleştiği bilinmektedir. Buna göre, şehirsel büyümeyi etkileyen temel parametreler arasında üniversitelerin konumu, mevcut yerleşme alanlarının çeperinde konut alanlarının inşa edilmesi ve yeni sanayi işletmelerinin kurulması sayılabilir.

2001 yılındaki arazi örtüsü/kullanımı sınıfları bir önceki döneme göre mekânsal olarak incelendiğinde tarım alanlarının azalışı ile yapay alanların artışı net bir şekilde fark edilmektedir (Şekil 6). Tarım alanlarının azalışı ve şehirlerin büyümesi, bölgenin doğal karakterli yapısının 2000'li yıllardan itibaren değişeceğine dair bir anlam taşımaktadır. Böylece, mekânsal süreç içerisinde 2001 yılı için, insanın mekânsal işgalinin en net gözlemlendiği yapay karakterli eğilim sürecinin başlangıç evresi olduğu söylenebilir. Özellikle bölgenin kuzeyinde ve şehirlerin çeperlerinde meydana gelen tarım alanlarındaki azalma yapay alanların büyümesi ile açıklanmaktadır. 2001 yılında 18.225 ha ile çalışma alanının \%2,4'ünü oluşturan ve 1995 yllına göre 5.500 ha alan kazanan yapay alanlar sınıfının genellikle yarı doğal alanlar ile tarım alanlarının dönüşümü sonucu ilerleme 
kaydettiği söylenebilir. Bu dönemde üç şehir için de şehirsel büyüme genellikle kuzey yönlü ve şehirleri birbirine bağlayan karayolu boyunca gerçekleşmiştir. Mersin şehrinin kuzey yönlü yayılış sahası, özellikle kıyıya dik uzanan ana caddelerin kuzey kesimindeki doğu-batı doğrultusunda yer alan konut gelişim adacıkları ile ifade edilmektedir. 1995 yılındaki etki alanının çeperine doğru büyüme gösteren Tarsus şehri için doğudaki Adana-Mersin karayolu ile Adana-Pozantı karayolu boyunca yeni gelişme alanlarının da varlığından söz edilebilir. Adana şehrinin kuzeybatısındaki gelişim bölgesi Adana-Erdemli Otoyolu'nun kuzeyinde konumlanan ve otoyolu dik kesen ana caddeler boyunca meydana gelen şehirsel yayılış alanını temsil etmektedir. Kuzeydoğu ve doğu yönlü gelişim bölgeleri ise Adana-Mersin karayolu ile Adana-İmamoğlu karayolu güzergahındaki mevcut yapay alanların çevresinde gerçekleşen şehirsel ilerlemeyi tanımlamaktadır. Her ne kadar bu şehirsel büyüme yerleşme odaklı olarak gelişse de şehrin doğusundaki Hacı Sabancı OSB gelişme alanı sanayi odaklı bir büyümenin sonucudur.

2007 yılında bir önceki döneme göre tarım alanları, orman alanları ve yapay alanlarda artış meydana gelirken; yarı doğal alanlar ile sulak alanlarda azalma kaydedilmiştir (Şekil 6). Özellikle bölgenin ve Mersin-Tarsus karayolunun kuzeyi ile göl ve baraj kıyılarındaki yarı doğal alanların tarımsal üretim için dönüştürülmesi sonucunda tarım alanlarında artış, yarı doğal alanlarda azalış gerçekleşmiştir. Buna ilaveten, Akyatan Gölü kıyılarında kumul erozyonunu önlemek ve nesli tehlike altında olan hayvanların yaşamsal faaliyetlerini gerçekleştirmeleri için yapılan ağaçlandırma faaliyetleri (WWF, 2020) bölgedeki orman alanlarının artışı ile sulak alanlarının azalışı ile sonuçlanmıştır. 2007 yllında bölgenin \%2,7'sini oluşturan yapay alanlar sınıfi 2001 y1lından bu yana 2.114 ha alan kazanarak 20.339 ha alana ulaşmıştır. Mersin ve Tarsus şehirlerinde kuzey eksenli yayılış devam ederken Adana şehrinde batı ve kuzeydoğu yönlü bir gelişimden söz edilebilir. Mersin şehrinde mevcut konut alanlarının çeperinde inşa edilen yeni yaşam alanları, 2003 yılında kurulan Palm City AVM ve kuzeydeki Toroslar Küçük Sanayi Sitesi bu dönemdeki şehirsel büyümenin yerleşme, ticaret ve sanayi odaklı meydana geldiğinin bir göstergesidir. Mersin-Tarsus OSB bünyesindeki sanayi tesislerinin artışı ve Tarsus'un doğu kanadındaki Kemalpaşa Sanayi Sitesi alanında yeni işletmelerin kurulması bölgedeki sanayi fonksiyonunun yıllara bağlı olarak geliştiğini ifade etmektedir. Ayrıca Adana şehrinin batısında Adana'yı Tarsus'a bağlayan karayolunun güney ve kuzey kanadı boyunca yeni sanayi işletmelerinin kurulması sonucu yapay alanlar sınıfı büyüme kaydetmiştir. Şehrin kuzeybatı ve kuzeydoğusunda ise yeni konut alanları göze çarpmaktadır.
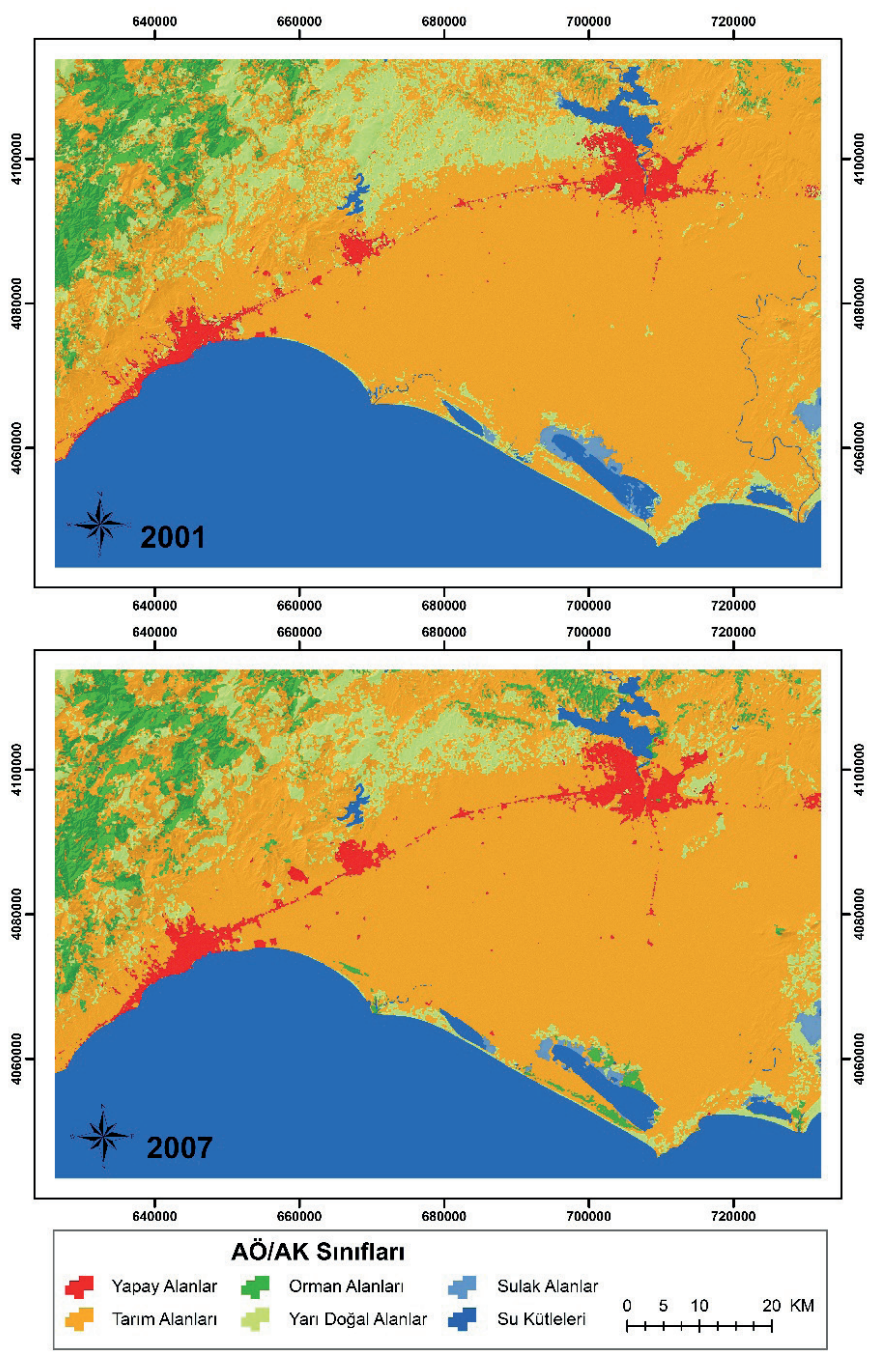

Şekil 6: 2001 ve 2007 yıllarının arazi örtüsü/kullanımı haritaları. Figure 6: Land cover/use maps of 2001 and 2007.

2013 y1lında orman alanları ile yapay alanların etkinlik sahalarında artı̧̧ devam ederken, yarı doğal alanlarda azalış meydana gelmiştir. 2007 yılındaki mevcut orman alanlarının çevreye doğru genişlemesiyle özellikle bölgenin kuzeyi, kuzeydoğusu ile Akyatan Lagünü'nün Akdeniz'e paralel uzandığı alanda ormanlık arazilerde ilerleme görülmüştür (Şekil 7). Buna ilaveten Berdan Barajı kuzeyinde, Yumurtalık Lagünü çevresinde ve Akdeniz kıyılarındaki arazilerin tarım alanlarına dönüştürülmesi sonucunda yarı doğal alanlarında azalma meydana gelmiştir. 2013 yılında 27.189 ha ile toplam sahanın \%3,7'sini oluşturan yapay alanlar sinıfi 2007 yılına göre alansal olarak 6.850 ha büyüme kaydetmiştir. 2007 y1lı ile 2013 y1lı arasındaki 6 yıllık süreçte her üç şehrin kuzey yönlü gelişimi devam ederken, Mersin'in doğu, Adana'nın batı eksenli büyümesi şehirlerin birbirleriyle birçok anlamdaki etkileşimini doğrular niteliktedir. Mersin şehrinin batı kıyıları yeni site yerleşmeleri ve kıyı turizmine yönelik konaklama tesislerinin 


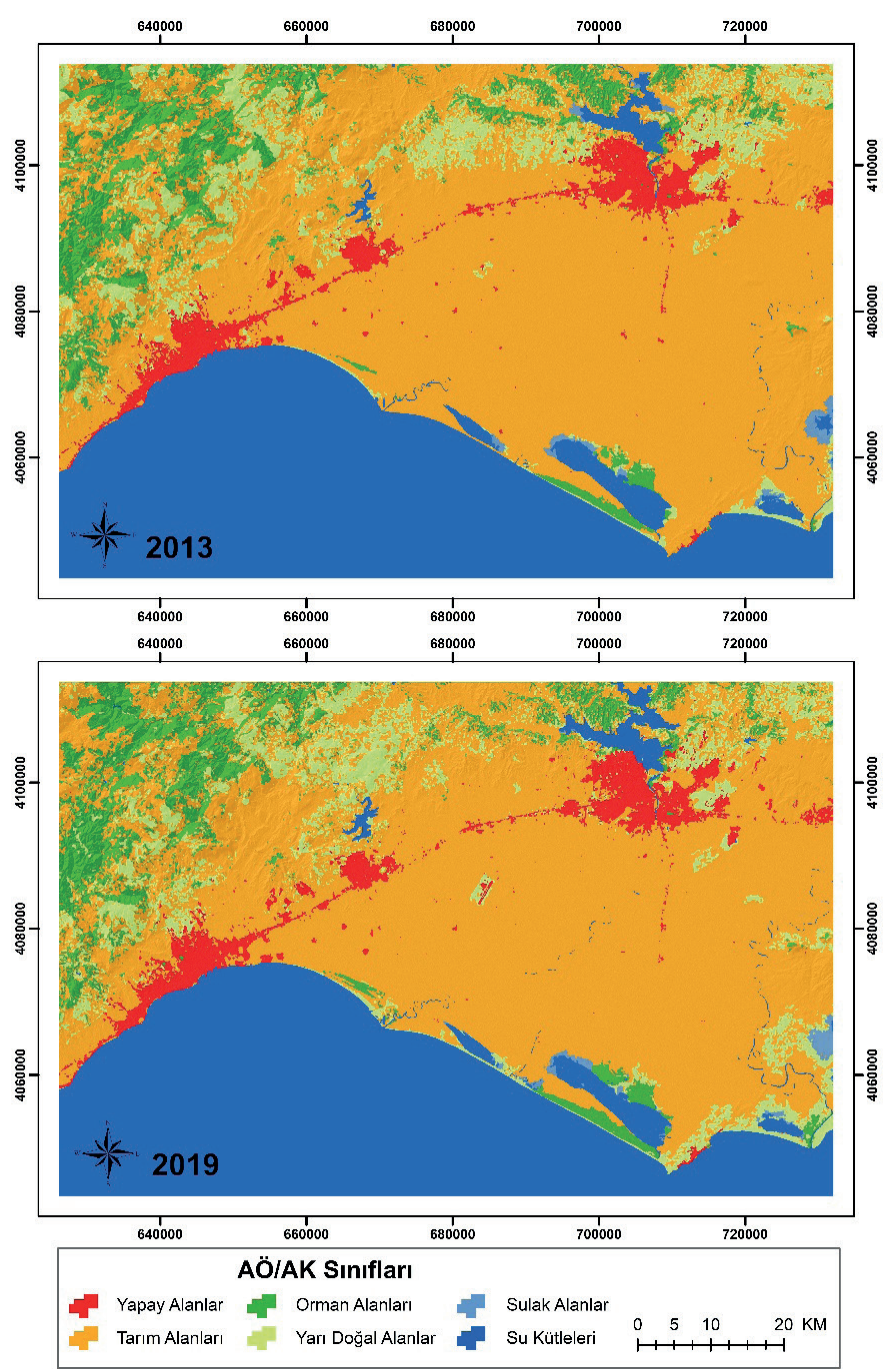

Şekil 7: 2013 ve 2019 yıllarının arazi örtüsü/kullanımı haritaları. Figure 7: Land cover/use maps of 2013 and 2019.

kurulması; kuzey eksenli büyüme ise genellikle 2007 y1lındaki yapay alanların çevreye doğru yayılması ve yeni konutların inşa edilmesi sonucunda gerçekleşmiştir. Bunun yanı sıra şehrin kuzeyinde 2013 yılında kurulan Mersin Stadyumu, 2007 yılından sonra kurulan Mersin Oto Galericiler Sitesi, Güneş Enerjisi Santral alanı ve depolama tesisleri şehrin sosyal, kültürel ve endüstriyel gibi farklı fonksiyonların bünyesinde yayıldığını göstermektedir. Mersin şehrinin doğu kanadında, Mersin-Tarsus karayolunun kuzeyinde ve Mersin-Tarsus OSB'nin batısında yer alan Mersin-Tarsus 2. OSB 2013 yılındaki yapay alanlar gelişme alanlarından birini teşkil etmektedir. Tarsus şehrinde 2007 yılından beri kuzey yönlü gelişimini devam etmiş ve özellikle şehrin kuzeybatı ve kuzeydoğu kanadındaki konut alanlarında büyüme meydana gelmiştir. Ayrıca Tarsus-Adana karayolu üzerindeki sanayi işletmelerinin artışına ilaveten, güneyde 2013 yılında temelleri atılan Çukurova Havalimanı'nın inşaat alanı iki şehir arasındaki yapay alanlar sınıfının gelişme alanlarını temsil etmektedir. 2007 yılı ile 2013 yılları arasında Adana şehri batı ve kuzeydoğu eksenli gelişiminin yanı sıra, doğudaki AdanaCeyhan karayolunun üzerinde de büyüme kaydetmiştir. Genellikle konut gelişimi ile temsil edilen Adana şehrindeki büyüme, Çukurova Üniversitesi'nin doğusunda yer alan Koza Arena Stadı ile Adana-Ceyhan karayolunun güneyindeki Adana Çimento Fabrikası ve doğusundaki Hacı Sabancı OSB etkinlik sahası söz konusu konut dışı gelişme alanlarını da içermektedir.

2019 yılında çalışma alanının \%52,3'ünü kaplayan tarım alanları 1989 yılından beri çalışma alanının en geniş sahası olma durumunu korumuştur. Bu özelliği yaratan ana etkenler; çalışma alanının oldukça büyük bir arazi üzerinde bulunması ve Çukurova tarım alanının bölgede geniş yer kaplamasıdır (Şekil 7). Diğer arazi örtüsü/kullanımı sınıfları 2013 yılındaki mekânsal örüntüye benzerlik göstererek sırasıla bölgenin \%28'ini su kütleleri, \%7,9'unu yarı doğal alanlar, \%7,6'sını orman alanları, \%3,8'ini yapay alanlar ve \%0,4'ünü sulak alanlar oluşturmaktadır. Doğrusal hat boyunca ve kuzey yönlü gelişimin yaşandığı son 6 yıllık dönemde yapay alanlar 1193 ha büyüme kaydederek günümüzde yaklaşık 28382 ha alana ulaşmıştır. Buna göre Mersin, Tarsus ve Adana şehirlerinin 2013 yılından bu yana esasen batı ve kuzey eksenli büyüdüğü ve bu büyümenin genellikle yerleşme, endüstriyel, ticari, sosyal ve kültürel karakterli olarak gerçekleştiği bilinmektedir (Adıgüzel, Toroğlu ve Kaya, 2015). Son dönemdeki bölgesel projelerin çalışma alanında yer aldığı konumları geçmişten günümüze meydana gelen şehirsel büyümenin ilerleyen dönemlerde de kuzey merkezli olarak aynı yönde süreceğinin göstergesidir. Mersin'de 2015 y1lında kurulan Mersin Şehirleraras1 Otobüs Terminali (MEŞOT) ve 2017 yılında açılışı yapılan Mersin Şehir Hastanesi kurumlarının Adana-Erdemli Otoyolu Mersin çıkışının doğusunda inşa edilmesi şehrin kuzey yönlü büyüme alanlarından birini teşkil etmektedir. Ayrıca kıyı bölgesi ile üniversiteyi birbirine bağlayan ana caddelerin çeperinde yer alan yüksek katlı binalar, apart daireler, yurtlar, yaşam kompleksleri, ticaret ve eğlence alanları genellikle öğrenci odaklı büyümenin bir sonucudur. Tarsus şehrinin batı, kuzey ve kuzeybatı yönlü büyümesi genellikle konut ve eğitim alanları odağında meydana gelmiştir. Genellikle otoyolun güney çeperinde ve şehrin batısında yer alan toplu yaşam merkezleri ve yüksek katlı lüks sitelerle temsil edilen konut gelişim bölgelerinde kolej tipi özel okulların da faaliyet alanları bulunmaktadır. Tarsus-Adana karayolu üzerinde Mercedes-Benz otomotiv sanayi alanı, 2013 yılında inşaatı başlayan ve günümüzde faaliyette olan Tarsus Ceza İnfaz Kurumları Kampüs alanı ile aynı yıl temelleri atılan ve kurulumu devam eden Çukurova Havalimanı inşaat sahası 
şehirsel büyüme alanlarından bazılarıdır. Adana şehri özellikle bat1, kuzey ve doğu yönlerinde sanayi, yerleşme ve sosyal kurumlar özelinde genişleme kaydetmiştir. Ayrıca şehrin kuzeyi ve Seyhan Baraj Gölü kenarı; günümüzde yüksek gelir gruplarının yerleştiği ve rekreasyon faaliyetleri amacıyla ziyaret edilen çekim merkezi konumundadır. Seyhan Baraj Gölü'nün güneydoğu ucunda yer alan Çukurova Üniversitesi, Koza Arena Stadı ve 2017 yılında faaliyete geçen Adana Şehir Hastanesi gibi cazibe alanları şehrin bu bölgeye doğru büyüdügünün ve yeni yapılan yüksek katlı binalarla gelişimin bu yönde süreceğinin göstergesidir.

\section{2. Şehirsel Büyümenin Mekansal Etkileri}

1989 yılından günümüze kadar geçen yaklaşık 30 y1llık dönemde meydana gelen yeni mekânsal olarak düzenin inşa edilme süreci; arazi örtüsü ve kullanımı sınıfları değişimlerinin karşılaştırılması ve yapay alanların büyümesiyle değişen şehir sınırlarının yarattığı mekânsal dönüşümler bağlamında değerlendirilmiştir. 1989 ile 2019 yılları arasında Mersin, Tarsus ve Adana hattındaki her bir arazi örtüsü ve kullanımı sınıfının kapladıkları alan bakımından artış ve azalışları ya dengesiz bir seyir izlemiş ya da benzer seyirlerde kalmıştır (Tablo 4). Fakat sadece yapay alanlar sınıfının son 30 yıllık dönemde yayılış alanı sürekli olarak artış eğiliminde olmuştur (Şekil 8). Toplam 745.324 ha sahayı kaplayan çalışma alanının 1989 yılında \%1,6'sını oluşturan yapay alanlar mekânsal olarak sürekli artarak günümüzde 28.382 ha alana ulaşmıştır.

Bölgenin en geniş alanını kaplayan tarım alanları sınıfı söz konusu süreçte artış ve azalışlarla dalgalı seyir izlemesine rağmen toplamda 61.280 ha alan kazanım ile günümüzde çalışma alanının yaklaşık yarısına karşılık gelmektedir. Benzer bir durum gösteren orman alanları ise çalışma alanında \%3,6'lık oranını toplamda 29.713 ha artarak \%7,6'ya yükseltmiştir. Yarı doğal alanlar ile sulak alanlar sınıfları 1989 ile 2019 yılları arasında

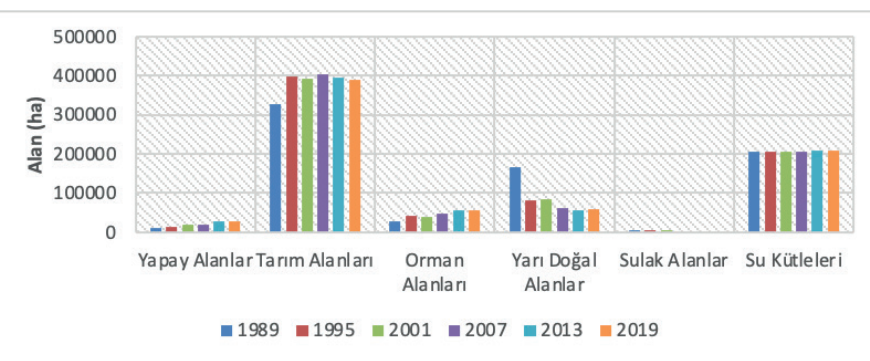

Şekil 8: 1989-2019 yılları arasındaki arazi örtüsü/kullanımı değişimleri. Figure 8: Land cover/use changes between 1989 and 2019.

alan değişimi bakımından azalış gösteren arazi örtüsü ve kullanımı sınıflarıdır.

1989 y1lında 167.041 ha alan ile bölgenin \%22,4'ünü oluşturan yarı doğal alanlar günümüzde 58.995 ha alana gerilemiş ve böylece 30 ylllık süreçte 108.046 ha alan kaybetmiştir. Oldukça dar bir alanda yer alan sulak alanlar sınıfının etkinlik alanı sürekli azalma eğilimi seyrederek günümüzde \%0,4 oranında varlığını korumaktadır. Bölgenin ikinci en geniş sahası konumunda olan su kütleleri sınıfında ise önemli bir değişim meydana gelmemiştir. Sonuç olarak, tüm diğer arazi örtüsü ve kullanımı sınıflarına nazaran yapay alanlar sınıfı geçmişten günümüze sürekli artış eğilimi gösteren tek sınıf olmuştur. Bu durum üç ana şehrin odağında gelişen şehirsel büyümenin yıllara bağlı olarak ne kadar istikrarlı gerçekleştiğinin bir göstergesidir. Gelecek dönemlerde de yapay alanlar sınıfında meydana gelen artışın devam edeceği ve şehirlerin daha da büyüyerek bölgedeki etkinlik alanını genişleteceği düşünülmektedir.

Mersin, Tarsus ve Adana şehirlerinin genel olarak 1989 yılındaki yayılış alanlarından çepere doğru büyüdüğü ve üç şehri birbirine bağlayan çizgisel hat boyunca geliştikleri net bir şekilde görülmektedir (Şekil 9). Bu durum birçok yönden birbirleriyle etkileşim halinde olan şehirlerin yıllar geçtikçe artan ilişkilerinin

Tablo 4: 1989-2019 yılları arasındaki arazi örtüsü/kullanımı sınıflarının kapladığı alanlar ve değişimleri (ha, \%). Table 4: The fields and changes of land cover/use classes between 1989 and 2019 (ha, \%).

\begin{tabular}{|c|c|c|c|c|c|c|c|c|c|c|c|c|c|}
\hline & \multicolumn{2}{|c|}{1989} & \multicolumn{2}{|c|}{1995} & \multicolumn{2}{|c|}{2001} & \multicolumn{2}{|c|}{2007} & \multicolumn{2}{|c|}{2013} & \multicolumn{2}{|c|}{2019} & \multirow{2}{*}{$\begin{array}{c}\text { 1989-2019 Arası Alan } \\
\text { Değişimi (ha) }\end{array}$} \\
\hline & ha & $\%$ & ha & $\%$ & ha & $\%$ & ha & $\%$ & ha & $\%$ & ha & $\%$ & \\
\hline 1 & 11.600 & 1,6 & 12.725 & 1,7 & 18.225 & 2,4 & 20.339 & 2,7 & 27.189 & 3,7 & 28.382 & 3,8 & 16.782 \\
\hline 2 & 328.603 & 44,1 & 399.251 & 53,5 & 392.776 & 52,7 & 404.499 & 54,3 & 396.469 & 53,2 & 389.883 & 52,3 & 61.280 \\
\hline 3 & 26.536 & 3,6 & 41.174 & 5,5 & 38.712 & 5,2 & 48.057 & 6,4 & 56.038 & 7,5 & 56.247 & 7,6 & 29.713 \\
\hline 4 & 167.041 & 22,4 & 81.884 & 11 & 84.872 & 11,4 & 63.093 & 8,5 & 55.153 & 7,4 & 58.995 & 7,9 & -108.046 \\
\hline 5 & 6.266 & 0,8 & 4.201 & 0,6 & 5.160 & 0,7 & 3.261 & 0,4 & 3.136 & 0,4 & 2.813 & 0,4 & -3.453 \\
\hline 6 & 205.278 & 27,5 & 206.089 & 27,7 & 205.579 & 27,6 & 206.075 & 27,7 & 207.339 & 27,8 & 209.003 & 28 & 3.726 \\
\hline Toplam & 745.324 & 100 & 745.324 & 100 & 745.324 & 100 & 745.324 & 100 & 745.324 & 100 & 745.324 & 100 & \\
\hline
\end{tabular}

Arazi Örtüsü/ Kullanımı Sınıfları (1: Yapay Alanlar, 2: Tarım Alanları, 3: Orman Alanları, 4: Yarı Doğal Alanlar, 5: Sulak Alanlar, 6: Su Kütleleri) 


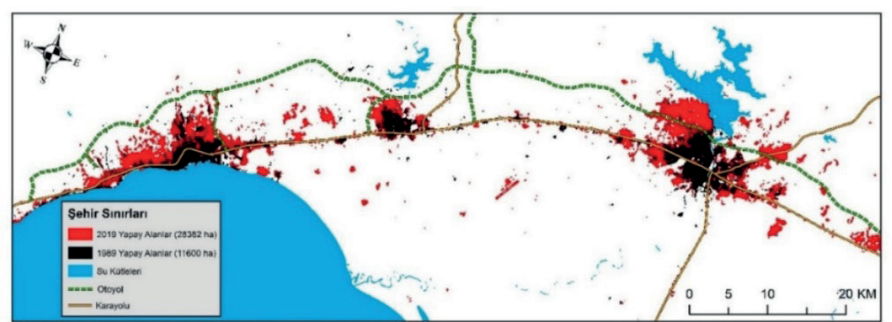

Şekil 9: Şehirsel büyüme süreci.

Figure 9: Urban growth process.

mekana nasıl yansıdığını ve mekanı nasıl şekillendirdiğini açıkça göstermektedir. Ayrıca söz konusu ilişkilerin şehirler arasındaki sürdürülebilirliğinin özellikle ulaşım sistemleriyle sağlandığı ve Mersin-Adana karayolunun bölgedeki mekânsal değişim üzerindeki etkin rolünün hissedildiği söylenebilir. Buna ilaveten üç şehir için de kuzey yönlü büyümenin genellikle şehrin dar ve sıkışı alanlarından kaçmak isteyen yüksek gelir grubundaki nüfusun sakin ve rahat bir mekan arayışından kaynaklandığı söylenebilir.

Arazi örtüsü/kullanımı sınıflarının farklı yıllar dahilindeki değişiminin analiz edilmesinin yanı sıra şehirsel büyümenin genellikle hangi arazi örtüsü ve kullanımı sınıfları üzerinde meydana geldiğinin incelenmesi mekânsal sürdürülebilirlik hakkında önemli bilgiler sunmaktadır. Buna göre 1989 yılından 2019 y1lına kadar geçen sürede 8.811 ha tarım alanı, 9.252 ha yarı doğal alan ve 52 ha su kütleleri olmak üzere toplamda 18.115 ha alan yapay alanlar sınıfına dönüşmüştür (Şekil 10). Böylece şehirlerin çevrelerindeki tarım arazileri ve kuzey bölgelerdeki yarı doğal alanlar üzerinde büyüdüğü açıkça fark edilmektedir.

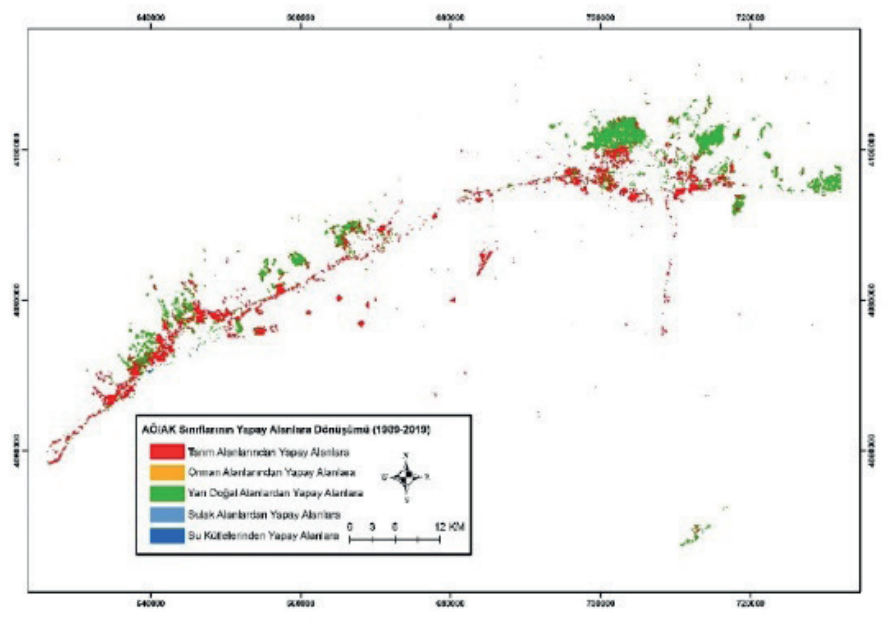

Şekil 10: 1989 ve 2019 yılları arasındaki arazi örtüsü/kullanımı sınıflarının yapay alanlara dönüşümü.

Figure 10: The conversion of land cover/use classes to artificial areas from 1989 to 2019.
Bölgesel çapta gerçekleştirilen veya gerçekleştirilmesi planlanan yerleşme, sanayi, ulaşım gibi farklı fonksiyonlardaki büyük ölçekli projelerin de tarım alanları ile doğal alanların sürdürülebilirliğini tehdit edebilir. Gerek yeni konut alanları bölgeleri gerekse Çukurova Havalimanı ve Tarsus Gıda İhtisas OSB gibi ulusal/uluslararası projeler bölgenin en verimli tarım arazileri ve doğal alanlar üzerinde inşa edilmektedir. Sarıçam Buruk Mahallesi bünyesinde bulunan konut inşaat alanlarının yapay alanlar sınıfı ile dolacağı öngörüsü bölgede yer alan ve aktif olarak işletilen tarım arazilerinin tahrip edilmesi sorununu gündeme getirmektedir. Ayrıca Çukurova Bölgesel Havalimanı için hazırlanan ÇED raporuna göre; projeye ayrılan 800 hektarlık alanın tarım arazisi olduğu, 5403 sayılı 'Toprak Koruma ve Arazi Kullanımı' kanununun 13. Maddesinin (d) bendinden yararlanarak alternatif alanın bulunmadığı ve kamu yararı göz önüne alınması sonucunda bu tarım alanının amaç dışı kullanımı planlanmıştır (ÇED, 2009). Buna göre havaalanı inşaat sahasının sulu tarım niteliğindeki I., II. ve III. sınıf tarım arazisi üzerinde bulunduğu bilinmektedir (ÇED, 2009) (Fotoğraf 1). MersinAdana Planlama Bölgesi 1/100.000 ölçekli Revizyon Çevre Düzeni Planı bünyesindeki Tarsus (Berdan) Barajı'nın kuzeydoğusunda yer alan tarım alanlarının statüsü değiştirilerek Tarsus Gıda İhtisas Organize Sanayi Bölgesi ilan edilmiştir (ÇŞB, 2017). Mersin Liman bölgesinde faaliyet gösteren ağır

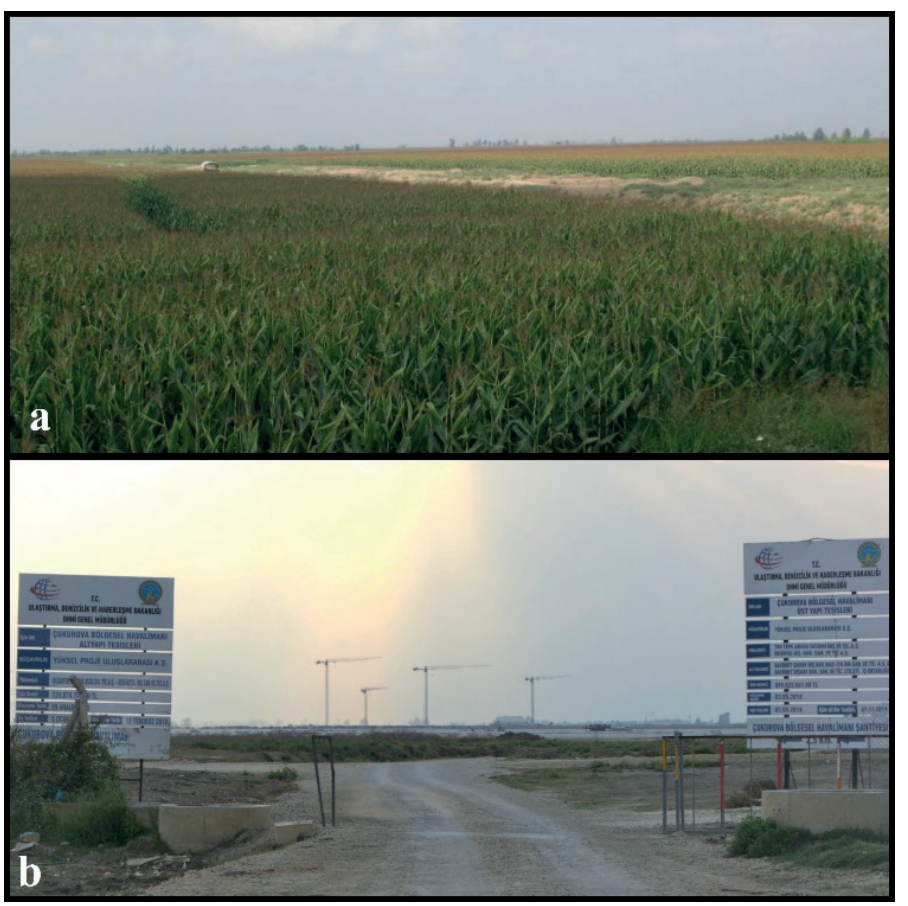

Fotoğraf 1: Çukurova Havalimanı (a: inşaat öncesi proje alanı (Kaynak: Çukurova Bölgesel Havalimanı Projesi ÇED Raporu, 2009) b:inşaat aşaması)

Photo 1: Cukurova Airport (a: pre-construction project area (ÇED, 2009) b: construction phase) 
metal, plastik tesisleri ve petrol dolum istasyonları ile son dönemde özel endüstriyel bölgesi olarak ilan edilen Toros Tarım San. ve Tic. A.Ş. işletmelerinin şehrin tarımsal, çevresel ve biyolojik fonksiyonlarına zarar verdiği düşünülmektedir (ÇŞB, 2020). Öyle ki, Toros Tarım endüstriyel bölgesinin inşa edileceği alanda bulunan geniş çayırlıklar ve ormanlık alan bölgenin doğal karakterli bir yapıya sahip olduğunu göstermektedir. Bu durum işletmenin üreteceği veya atık olarak bırakacağı maddelerin yakınlardaki tarım alanlarını, mekanın doğal karakterli dokusunu ve canlı yaşamını tehdit ederek doğaya zarar vereceği tahmin edilmektedir.

\section{SONUÇ}

Şehir yerleşmelerinin bünyesinde barındırdığı nüfusun arazi örtüsü ve kullanımı üzerinde yarattı̆ğ baskı ve işgal durumu beraberinde mekânsal sürdürülebilirlik ve tarım alanlarının amaç dışı kullanımı sorunlarını gündeme getirmektedir. Bu çalışmada, şehirsel yığılma bölgelerinden biri olan Mersin, Tarsus ve Adana hattında geçmişten günümüze meydana gelen arazi örtüsü/ kullanımı değişimleri, şehirsel büyümenin fiziksel yayılımı ve mekânsal dönüşümün alansal değişimi incelenmiştir. Buna yönelik, 1989, 1995, 2001, 2007, 2013 ve 2019 olmak üzere 6 y1l aralıklarla elde edilen Landsat uydu görüntüleri CORINE arazi örtüsü sistemi referans alınarak kontrollü sınıflandırma yöntemi ile analiz edilmiştir. Sınıflandırılmış arazi örtüsü/kullanımı haritalarına uygulanan doğruluk analizi sonuçlarına göre; \%90'ın üzerinde genel doğruluk ve \%85'in üzerinde Kappa değerlerine ulaşılmıştır.

Analiz sonuçlarında elde edilen bulgulara göre, yaklaşık son 30 yıllık süreçte yayılış alanı sürekli olarak artış eğiliminde olan tek sınıfın yapay alanlar olduğu, diğer sınıfların ise dalgalı bir seyir izlediği ortaya çıkmıştır. 1989 ile 2019 yılları arasında yapay alanlar sınıfı 16.782 ha artış ile mevcut alanını ikiye katlamıştır. Yani 1989 yılında 11.600 ha ile bölgenin \%1,6'sını oluşturan yapay alanlar sinıfı günümüzde 28.382 ha alana ulaşarak çalışma alanının \%3,8'ini kaplamaktadır. Bu süreçte üç şehrin genellikle çevrelerine doğru, kuzey yönlü ve MersinAdana karayolu üzerinde çizgisel hat boyunca büyüdüğü sonucuna ulaşılmıştır. $\mathrm{Bu}$ durumu meydana getiren temel faktörler arasında ana ulaşım sistemleri, endüstriyel ve ticari alanlar, sosyal ve kültürel tesisler ile bölgesel çaptaki çekim merkezleri gibi farklı faaliyet alanları sayılabilir. Fakat söz konusu şehirsel büyümenin 8.811 ha tarım alanı üzerinde gerçekleşmesi mekânsal tahribatı ve tüketimi ifade etmektedir. Geçmişten günümüze gerçekleşen tarım alanlarının amaç dışı kullanımı sorununun bölgesel ölçekte yapılan yeni projelerle gelecek dönemlerde de devam edeceği düşünülmektedir. Bölgenin ekonomisini şekillendiren ve büyük ölçüde kontrol eden tarım alanlarının şehirsel büyüme için işgal edilmesi olgusu mekânsal sürdürülebilirliği tehdit eder niteliktedir. Bunun sonucunda, mekânsal sürdürülebilirliği kontrol etmek ve verimli tarım arazilerinin kaybını önleyerek bölgesel ekonomik potansiyeli korumak için şehirlerin özellikle kuzey yönlü büyümesi olumlu bir gelişimdir ve büyümenin bu yönde devam etmesi desteklenmektedir. Buna yönelik olarak daha planlı ve kontrollü şehirsel büyüme bölgelerinin tespit edilmesinin amaçlandığı geleceğe yönelik simülasyonlar geliştirilerek kent yönetim planlamalarına destek sağlanabilir.

Hakem Değerlendirmesi: Dış bağımsız.

Yazar Katkıları: Çalışma Konsepti/Tasarım- S.Y.G.; Veri Toplama- S.Y.G.; Veri Analizi/ Yorumlama- S.Y.G.; Yazı Taslağı- S.Y.G.; İçeriğin Eleştirel İncelemesi- S.S.; Son Onay ve Sorumluluk- S.Y.G., S.S.

Çıkar Çatışması: Yazarlar çıkar çatışması bildirmemiştir.

Finansal Destek: Yazarlar bu çalışma için finansal destek almadığını beyan etmiştir.

Peer-review: Externally peer-reviewed.

Author Contributions: Conception/Design of Study- S.Y.G.; Data Acquisition- S.Y.G.; Data Analysis/Interpretation- S.Y.G.; Drafting Manuscript- S.Y.G.; Critical Revision of Manuscript- S.S.; Final Approval and Accountability- S.Y.G., S.S

Conflict of Interest: The authors have no conflict of interest to declare.

Grant Support: The authors declared that this study has received no financial support.

\section{KAYNAKÇA/REFERENCES}

Açıksöz, S., Topay, M., \& Yılmaz, B. (2008). Arazinin yanlış kullanımından kaynaklanan sorunlar: Bartın kenti örneği. Süleyman Demirel Üniversitesi Orman Fakültesi Dergisi, 9(1), 155-167.

Adıgüzel, F., Toroğlu, E., \& Kaya, Ö. (2015). Kentsel gelişme ile ulaşım ilişkisi: Adana örneği. Turkish Studies, 10(6), 27-46. doi:http://dx. doi.org/10.7827/TurkishStudies.8109

Ahmed, B., \& Ahmed, R. (2012). Modeling urban land cover growth dynamics using multi-temporal satellite images: A case study of Dhaka, Bangladesh. ISPRS International Journal of Geo-Information, 1(1), 3-31. doi:10.3390/ijgi1010003

Alphan, H. (2003). Land-use change and urbanization of Adana, Turkey. Land degradation \& development, 14(6), 575-586. doi:10.1002/ ldr.581

Avc1, S. (1993). Türkiye'de şehir ve şehirli nüfusun dağılış1. Türk Coğrafya Dergisi, (28), 249-269.

Bayar, R., \& Karabacak, K. (2017). Ankara ili arazi örtüsü değişimi (2000-2012). Coğrafi Bilimler Dergisi, 15(1), 59-76.

Bayrakdar, C., Döker, M. F., \& Keserci, F. (2020). Polyelerde hatalı arazi kullanımların sebep olduğu afetlere bir örnek: 31 Ocak 2019 Kayaköy Polyesi taşkını. Coğrafya Dergisi, (41), 109-128. doi:10.26650/JGEOG2020-0046 
Bazin, T., \& de Tapia, S. (2015). Türkiye coğrafyası. İstanbul: İletişim Yayınları.

Belal, A., \& Moghanm, F. S. (2011). Detecting urban growth using remote sensing and GIS techniques in Al Gharbiya governorate, Egypt. The Egyptian Journal of Remote Sensing and Space Science, 14(2), 73-79. doi:10.1016/j.ejrs.2011.09.001

Berry, K. J., Johnston, J. E., \& Mielke Jr, P. W. (2014). A chronicle of permutation statistical methods. Cham: Springer.

Beyhan, B., Taubenböck, H., Suffa, S., Ullmann, T., Rauh, J., \& Dech, S. (2012). Urban growth and sprawl of Mersin city, Turkey: Change analysis based on earth observation and socio-economic data. Megaron, 7(1), 3-25.

Biricik, A. S., \& Kurt, H. (1998). 27 Haziran 1998 Adana Ceyhan depremi. Marmara Coğrafya Dergisi, (2), 95-121.

Boydak, M. (2008). Kızılçam ve toros sedirinde silvikültürel gelişmeler. Batı Akdeniz Ormancılık Araştırma Müdürlüğü 50. Yıl Etkinliği, 185-244.

Buhaug, H., \& Urdal, H. (2013). An urbanization bomb? Population growth and social disorder in cities. Global Environmental Change, 23(1), 1-10. doi:10.1016/j.gloenvcha.2012.10.016

Campari, I. (1996). Uncertain boundaries in urban. In P. A. Burrough \& A. U. Frank (Eds.), Book Uncertain boundaries in urban (pp. 5769).Gisdata 2. Taylor \& Francis Ltd.

Campbell, J. B., \& Wynne, R. H. (2011). Introduction to remote sensing. Guilford Publications.

ÇED. (2009). Çukurova Bölgesel Havaalanı Projesi. Retrieved from http://www.interport.com.tr/dokuman/cukurova_havaalani.pdf

Cengiz, A. E., Çavuş, Z. C., \& Koç, T. (2014). Çanakkale ve Kepez yerleşmelerinde sulu tarım alanları kentleşme ilişkisi. Coğrafi Bilimler Dergisi, 12(1), 69-88. doi:10.1501/Cogbil_0000000153

ÇŞB. (2017). Mersin-Adana Planlama Bölgesi 1/100.000 Ölçekli Revizyon Çevre Düzeni Planı Değişikliği (Mersin Tarsus Gıda İhtisas OSB) Plan Açılama Raporu. Retrieved from https://webdosya.csb. gov.tr/db/mpgm/editordosya/file/CDP_100000/ma/PLANDEGISIKLIGIACIKLAMARAPORU_24112017.pdf

ÇŞB. (2020). Mersin-Adana Planlama Bölgesi 1/100.000 Ölçekli Revizyon Çevre Düzeni Planı Değişikliği (Mersin İli, Akdeniz İlçesi, Karaduvar Mahallesi “Özel Endüstri Bölgesi”) Plan Açıklama Raporu. Retrieved from https://webdosya.csb.gov.tr/db/mpgm/ icerikler/plan-aciklama-raporu-20200212153258.pdf

Devlet İstatistik Enstitüsü (DİE). (1927-2000). Genel Nüfus Sayımlart. Retrieved from https://biruni.tuik.gov.tr/nufusmenuapp/menu.zul

Döker, M. F., \& Gül, A. (2019). Adapazarı'nda şehirsel büyüme süreci ve arazi kullanım değişiminin izlenmesi (1985-2019). Türk Coğrafya Dergisi, (73), 67-78. doi:10.17211/tcd.616796

Eastman, J. R. (2009). IDRISI Taiga guide to GIS and image processing. Clark Labs Clark University, Worcester, MA.

Eastman, J. R. (2016). TerrSet geospatial monitoring and modeling system. Clark University: Worcester, MA, USA.

Fang, C., \& Wang, J. (2013). A theoretical analysis of interactive coercing effects between urbanization and eco-environment. Chinese Geographical Science, 23(2), 147-162. doi:10.1007/s11769-013-0602-2
Franklin, S., \& Walker, C. (2010). Survey methods and practices. Statistics Canada. Social Survey Methods Division, Ottawa.

Göney, S. (1976). Adana Ovaları I. İstanbul Üniversitesi Edebiyat Fakültesi.

Gülersoy, A. E., Çelik, M. A., \& Sönmez, M. E. (2014). Tarsus şehrinin alansal gelişimine (1985-2011) ekolojik bakış. Electronic Turkish Studies, 9(2). doi:10.7827/TurkishStudies.6217

Hayır Kanat, M. (2016). Türkiye'nin yerleşme coğrafyası. M. Hayır Kanat (Ed.), Türkiye coğrafyası ve jeopolitiği kitabı içinde (s. 251289): Nobel Yayıncilik.

Horning, N. (2004). Selecting the appropriate band combination for an RGB image using Landsat imagery Version 1.0. New York (NY): American Museum of Natural History. Center for Biodiversity and Conservation.

Ishtiaque, A., Shrestha, M., \& Chhetri, N. (2017). Rapid urban growth in the Kathmandu Valley, Nepal: Monitoring land use land cover dynamics of a himalayan city with landsat imageries. Environments, 4(4), 72. doi:10.3390/environments4040072

Jensen, R. R., \& Shumway, J. M. (2010). Sampling our world. In B. Gomez \& J. P. Jones III (Eds.), Book Sampling our world (pp. 7790): John Wiley \& Sons.

Kaya, Ö., \& Toroğlu, E. (2015). Kayseri'nin şehirsel gelişiminin izlenmesi ve değişim analizi. Türk Coğrafya Dergisi, (65), 87-96. doi:10.17211/tcd.37722

Keleş, R. (2017). Kentleşme politikası. (16. bs.): İmge Kitabevi.

Kumar, J. A. V., Pathan, S., \& Bhanderi, R. (2007). Spatio-temporal analysis for monitoring urban growth-a case study of Indore city. Journal of the Indian Society of Remote Sensing, 35(1), 11-20. doi:10.1007/BF02991829

Lo, L. (2009). Sampling. In R. Kitchin \& N. Thrift (Eds.), Book Sampling (pp. 1-10): Elsevier.

Maktav, D., \& Erbek, F. S. (2005). Analysis of urban growth using multi-temporal satellite data in Istanbul, Turkey. International journal of Remote sensing, 26(4), 797-810. doi:10.1080/01431160512331316784

Mundia, C. N., \& Aniya, M. (2005). Analysis of land use/cover changes and urban expansion of Nairobi city using remote sensing and GIS International Journal of Remote Sensing, 26(13), 2831-2849. doi:10.1080/01431160500117865

Olğaç, İ., \& Doğan, M. (2020). Edirne şehrinin arazi kullanımının zamansal değişimi (1990-2018). Uluslararası Yönetim Akademisi Dergisi, 3(1), 26-36. doi:10.33712/mana.710859

Özdemir, H., \& Bayrakdar, C. (2007). 16 Kasım 2007 Tuzla Deresi taşkınının nedenleri üzerine bir araştırma (Silivri-İstanbul). Türk Coğrafya Dergisi, (49), 123-139. doi:10.17211/tcd.02208

Resmi Gazete. (2012). On dört ilde büyükşsehir belediyesi ve yirmi yedi ilçe kurulması ile bazı kanun ve kanun hükmünde kararnamelerde değişiklik yapılmasına dair kanun. Erişim Adresi: http://www. mevzuat.gov.tr/MevzuatMetin/1.5.6360.pdf.

Sandal, K. E., \& Gürbüz, M. (2003). Mersin şehrinin mekansal gelişimi ve çevresindeki tarım alanlarının amaç dışı kullanımı. Coğrafi Bilimler Dergisi, 1(1), 117-130. 
Sargıı, S. (2007). Türkiye'de üniversitelerin gelişim süreci ve bölgesel dağılımı. Süleyman Demirel Üniversitesi SBE Dergisi(5), 133-150.

Sönmez, M. E. (2011). Adana şehrinin alansal gelişimi ve yakın çevresinin arazi kullanımında meydana gelen değişimler. Türk Coğrafya Dergisi, (57), 55-69.

Sönmez, M. E., \& Aytuk, C. (2014). Akyatan Lagünü çevresinde arazi kullanımındaki değişimlerin zamansal incelenmesi ve ekosistem üzerindeki olumsuz etkilerinin belirlenmesi. Sosyal Bilimler Dergisi, 1(1), 25-39.

Tekeli, İ. (1998). Türkiye'de cumhuriyet döneminde kentsel gelişme ve kent planlamas1. 75 Yllda Değişen Kent ve Mimarlık, 1-24.

Tümertekin, E. (1973). Türkiye'de şehirleşme ve şehirsel fonksiyonlar. İstanbul Üniversitesi Edebiyat Fakültesi, Yayınları, İstanbul.

Türkiye İstatistik Kurumu (TÜİK). (2000-2020). Nüfus İstatistikleri $(A D N K S)$. Retrieved from https://biruni.tuik.gov.tr/medas $/$ : $\mathrm{kn}=95 \&$ locale $=\mathrm{tr}$

UN. (2018). Revision of world urbanization prospects. United Nations: New York, NY, USA.

USGS. (2020). Earth Explorer. Retrieved from https://earthexplorer. usgs.gov/
Wu, Y., Li, S., \& Yu, S. (2016). Monitoring urban expansion and its effects on land use and land cover changes in Guangzhou city, China. Environmental Monitoring and Assessment, 188(1), 54. doi:10.1007/ s10661-015-5069-2

WWF. (2020). Akyatan Yaban Hayatı Geliştirme Sahası. Retrieved from https://www.wwf.org.tr/ne yapiyoruz/doga_koruma/doal_alanlar/akyatanyabanhayatgelistirmesahas_

Yavan, N. (2014). Örneklem ve örnekleme yöntemleri. Y. Arı \& İ. Kaya (Eds.), Coğrafya araştırma yöntemleri kitab1 içinde (s. 155-174): Balıkesir: Coğrafyacılar Derneği.

Yener, H., Koç, A., \& Çoban, H. O. (2006). Uzaktan algılama verilerinde sınıflandırma doğruluğunun belirlenmesi yöntemleri. İstanbul Üniversitesi Orman Fakültesi Dergisi Seri B, 56(2), 71-88.

Yiğitbaşıŏlu, H., \& Uğur, A. (2010). Burdur Gölü havzasında arazi kullanım özelliklerinden kaynaklanan çevre sorunları. Ankara Üniversitesi Çevrebilimleri Dergisi, 2(2), 129-143. doi:10.1501/ Csaum_0000000032

Yüceşahin, M. M., Bayar, R., \& Özgür, E. M. (2004). Türkiye'de şehirleşmenin mekansal dağılışı ve değişimi. Coğrafi Bilimler Dergisi, 2(1), 23-39. doi:10.1501/Cogbil_0000000042 